\title{
Alzheimer's Disease and Mild Cognitive Impairment
}

\author{
Brendan J. Kelley, MD and Ronald C. Petersen, PhD, MD \\ Mayo Clinic, Department of Neurology, 200 First Street SW, Rochester, MN 55905, 507-284-4006, \\ FAX: 507-284-4074, E-mail: peter8@mayo.edu
}

\section{OVERVIEW}

As our society ages, age-related diseases assume increasing prominence as both personal and public health concerns. Disorders of cognition are particularly important in both regards, and Alzheimer's disease (AD) is by far the most common cause of dementia of aging. In 2000, the prevalence of $\mathrm{AD}$ in the United States was estimated to be 4.5 million individuals, and this number has been projected to increase to 14 million by $2050^{1}$. While $\mathrm{AD}$ is not an inevitable consequence of aging, these numbers speak to the dramatic scope of its impact. This review will focus on $\mathrm{AD}$ as well as the milder degrees of cognitive impairment that may precede the clinical diagnosis of probable $\mathrm{AD}$ such as mild cognitive impairment ${ }^{2}$.

One presumes a gradual pathological progression which begins with normal aging, evolves through clinically probable $\mathrm{AD}$ and culminates in neuropathologically proven $\mathrm{AD}^{3}$. It is likely that individuals pass through a transitional stage between normal aging and clinically probable $\mathrm{AD}$, as illustrated in Figure 1. This phase of mild cognitive impairment may be characterized by memory impairment associated with minimal or no functional decline. These individuals do not meet criteria for clinically probable $\mathrm{AD}$ yet are worthy of identification and monitoring.

In 2001, the American Academy of Neurology published three practice parameters, evidencebased medicine analyses of the extant literature on dementia ${ }^{4-6}$. One dealt with mild cognitive impairment ${ }^{5}$, the second with diagnostic issues concerning $\mathrm{AD}$ and other dementias ${ }^{4}$ and the third paper reviewed treatment recommendations for $\mathrm{AD}$ and other dementias ${ }^{6}$. These documents provide current assessments of diagnostic and management issues regarding AD.

\section{A. Normal Aging}

Implicit to a discussion of $\mathrm{AD}$ and mild cognitive impairment is knowledge about cognitive changes of normal aging. Characterization of these cognitive changes remains an active area of research, with no agreement on the nature or degree of impairment or the pathological substrate of that clinical picture. Consequently, the characterization of early changes of mild cognitive impairment remains difficult ${ }^{7}$. Normative data on a variety of neuropsychological tests for individuals up to age 100 years exists, as do criticisms of these data 8 , 9 . Some argue that existent normative data are contaminated by the inclusion of persons who would meet current definitions of mild cognitive impairment, and consequently the norms reflect more impairment than should be expected as a consequence of "normal aging" 9 . Exclusion of these individuals from the normative data presents a conundrum, and the recursive logic necessary to do so makes this impractical if not impossible.

Correspondence to: Ronald C. Petersen.

Publisher's Disclaimer: This is a PDF file of an unedited manuscript that has been accepted for publication. As a service to our customers we are providing this early version of the manuscript. The manuscript will undergo copyediting, typesetting, and review of the resulting proof before it is published in its final citable form. Please note that during the production process errors may be discovered which could affect the content, and all legal disclaimers that apply to the journal pertain. 
A meta-analysis investigating cognitive impairment prior to the diagnosis of $\mathrm{AD}$ indicated that preclinical deficits in global functioning, episodic memory, perceptual speed and executive functioning were indicative of the subsequent development of $\mathrm{AD}^{10}$. Among episodic memory parameters, delayed recall procedures produced the largest effect sizes, and the authors concluded that deficits in multiple cognitive domains preceded the clinical development of AD.

Research to more precisely delineate cognitive changes associated with normal aging may allow more accurate interpretation of very early cognitive changes and prediction of their pathologic substrates. At present, clinical judgment remains the best means of assessing mild cognitive impairment.

\section{B. Dementia}

Dementia implies a cognitive decline of sufficient severity to compromise a person's daily function. While diagnostic criteria vary depending upon dementia subtype, general features such as those found in the Diagnostic and Statistical Manual - III R (DSM III-R) remain useful 11. In general, they require memory impairment beyond what would be normal for aging and impairment of at least one other cognitive domain such as attention, language, visuospatial skills or problem solving. These deficits are of sufficient severity to compromise daily functional activities and do not occur in the setting of altered sensorium such as delirium or an acute confusional state. Once this type of cognitive impairment has been determined, the clinician must then determine the underlying nature of the dementia. In the DSM III-R definition, memory impairment is an essential feature of dementia. While this is true of many dementias, it is conceivable that patients with frontotemporal dementia or a Lewy body dementia might present with significant impairment of non-memory cognitive domains early in the disorder. Nevertheless, the DSM III-R criteria provide a practical reference point, particularly for Alzheimer's disease.

In an elderly person with gradually progressive amnestic disorder which has advanced to involve non-memory cognitive domains to a degree that these changes affect daily functioning, $\mathrm{AD}$ is the most likely diagnosis.

\section{ALZHEIMER'S DISEASE}

This dementia is slowly progressive with prominent memory disturbance appearing early in the clinical presentation 12 . As the disease progresses, other cognitive domains become involved and behavioral alterations also arise ${ }^{13-16}$. Alzheimer's disease is a degenerative disorder, and definitive diagnosis can only be made by post-mortem examination of the brain. The classic neuropathological features are neuritic plaques and neurofibrillary tangles 17 .

\section{A. Epidemiology}

Alzheimer's disease is an age-related phenomenon, and is the most common cause of dementia in the United States. The incidence of AD increases dramatically with age, doubling every five years after age $65^{18}$. The prevalence of $\mathrm{AD}$ rises dramatically with age, becoming quite common in the 70s and more so into the 80 s. While it is uncertain whether the incidence of Alzheimer's disease continues to rise into the 90s; the incidence of dementia increases rapidly in that age range. The prevalence of $\mathrm{AD}$ doubles every five years, and there is a greater prevalence of AD in women, likely reflecting their greater longevity $19-25$.

\section{B. Clinical Diagnosis}

The most commonly employed clinical criteria for diagnosis of $\mathrm{AD}$ are those listed in the Diagnostic and Statistical Manual, Fourth Revision (DSM-IV) ${ }^{26}$ or those established by the 
National Institute of Neurologic, Communicative Disorders and Stroke/Alzheimer's Disease and Related Disorders Association (NINCDS-ADRDA) work group 27. The DSM-IV criteria for dementia of the Alzheimer's type (Table 1) involve the development of memory impairment accompanied by impairment of one or more other cognitive domains including aphasia, apraxia, agnosia or disturbance of executive functioning. The cognitive impairments are gradually progressive, of sufficient severity to impair functional abilities, and cannot be accounted for by other neurologic or psychiatric disturbances. The American Academy of Neurology practice parameter found these criteria to be reliable ${ }^{4}$.

An adequate history is essential to establishing the diagnosis of dementia. It is critical to take the history from the patient as well as an informant who knows the patient well. Simple inquiry regarding changes in the patient's ability to carry out typical activities of daily living provide a valuable gauge of the severity of cognitive impairment. In addition to the history, instruments designed to screen for cognitive impairment such as the Mini-Mental State Examination (MMSE) ${ }^{28}$, the modified Mini-Mental State (3MS) ${ }^{29}$, the Blessed Orientation Memory Concentration Test ${ }^{30}$, the Kokmen Short Test of Mental Status ${ }^{31}$ or the Clinical Dementia Rating scale (CDR) 32 can be quite useful. None has been demonstrated to be superior to the others.

\section{General Neurologic Examination}

In early $\mathrm{AD}$, the general neurologic examination is typically normal with the exception of the mental status evaluation. Abnormalities such as parkinsonism, focal neurologic deficits, or deficits in other parts of the nervous system may suggest an alternative diagnosis. It is important to assess sensory functions since sensory deprivation can affect the mental status and neurologic examination. Finally, the neurologic examination should be complemented by a general medical examination looking for medical conditions which may contribute to cognitive impairment.

\section{Laboratory Tests}

The utility of a variety of laboratory tests in evaluating a patient with dementia was assessed in the American Academy of Neurology practice parameter ${ }^{4}$. The authors concluded that vitamin B-12 levels and thyroid functions should be routinely assessed in cases of dementia.

In practice, a variety of tests may be considered in evaluation of dementia, as outlined in Table 2. Although few of these have been demonstrated to actually have an impact on improving the dementia, they can be helpful in the appropriate clinical setting since medical conditions may impact cognitive function.

\section{E. Neuroimaging}

The American Academy of Neurology practice parameter recommended that a CT or MRI be done in most circumstances at the initial dementia assessment to exclude potentially treatable structural lesions such as subdural hematoma, neoplasm, and stroke ${ }^{4}$.

Atrophy of medial temporal lobe structures, e.g., the hippocampus, has been found in patients with $\mathrm{AD}$, but this atrophy may be nonspecific and while consistent with $\mathrm{AD}$, it may be seen in other conditions as well ${ }^{33}$. Longitudinal volumetric measurements of the hippocampal formation have indicated more rapid progression of atrophy among persons with AD than normal controls 34 . The utility of volumetric measurements of the entorhinal cortex remains controversial $35-37$. While atrophy of the hippocampus, amygdala, and entorhinal cortex is established in $\mathrm{AD}$, the role of these findings in the diagnostic evaluation of people having or at risk for developing $\mathrm{AD}$ remains to be defined ${ }^{38}$. 
Functional neuroimaging has been studied in $\mathrm{AD}$, and while several studies have suggested that SPECT imaging augments the clinician's acumen $39-43$, added discriminability has yet to be definitively demonstrated. PET scanning has shown promise in differentiation amongst dementias 44 and FDG-PET may be a useful adjunct in the diagnosis of $\mathrm{AD}^{45}$. There is literature validating the utility of FDG-PET in differentiating AD from frontotemporal dementia and the Centers for Medicare and Medicaid have approved for reimbursement the use of FDG-PET for this purpose. Some evidence suggests that FDG-PET may be useful in assessing people at risk for developing $\mathrm{AD}$, but longitudinal outcome data is not yet available 45 .

Proton MR spectroscopy has also shown promise in evaluating incipient cases of $\mathrm{AD}^{46}$, and possibly in differentiating among the various types of dementias 47 . This technique may be useful in assisting in the diagnosis of dementia in the future.

Recently, exciting new imaging techniques have been developed which allow antemortem detection of amyloid deposition in the brain through the use of the radioligand PET imaging studies $48-50$. Pittsburgh Compound B (PIB), while not ready for clinical use, provides the potential for detection of the onset of amyloid deposition prior to the development of clinical symptoms, as well as the opportunity of following amyloid-targeted therapies 51, 52. Another compound, FDDNP, which binds to both amyloid and tau was recently reported to differentiate between normal controls, $\mathrm{MCI}$ and $\mathrm{AD}{ }^{50}$. These developments may lead to important new research opportunities in the early diagnosis and treatment of $\mathrm{AD} 52$.

\section{F. Neuropsychological Testing}

Neuropsychological testing can help to determine if reported cognitive changes represent normal aging, $\mathrm{MCI}$, or signify $\mathrm{AD}$. In early $\mathrm{AD}$, subjects commonly have deficits in delayed verbal recall and learning, and may also exhibit impaired naming. A depressed subject may generate a flat learning curve over multiple trials to learn a list of words, but will be able to retain the amount learned after a delay. Frontotemporal dementia patients may have profound difficulties with executive function, sustained attention and speed of processing with relative sparing of naming and memory. While not diagnostic, these neuropsychological profiles can help to distinguish among various dementias. Neuropsychological testing can also provide a baseline against which to compare future evaluations. Consequently, depending upon the particular clinical situation, neuropsychological testing can be an important adjunct.

\section{G. Lumbar Puncture}

Several retrospective studies have found little evidence to recommend spinal fluid analysis in the routine evaluation of dementia in elderly patients ${ }^{53}$. Dementia characterized by a subacute mental status change, fever, nuchal rigidity, or in the setting of possible contributing processes such as systemic cancer or collagen vascular disease may warrant CSF analysis. Positive syphilis serology may be further evaluated by CSF examination. In immunocompromised patients, syphilis, fungal infections, lymphoma and other opportunistic infections must be considered. Individuals having a rapidly progressive or atypical clinical course and those presenting younger than age 60 may also prompt CSF analysis. Obviously, one must ascertain that there are no contraindications to the procedure.

\section{H. Genetic Testing}

Individuals presenting in their $30 \mathrm{~s}$, 40s or 50s with a family history suggestive of an autosomal dominant disease may merit testing for mutations on chromosomes 1,14 or 2154 . Testing should only be undertaken in the setting of appropriate genetic counseling, since the results may have significant impact on the patient and family members. Genetic testing for specific mutations is not typically useful in typical late onset AD. 
Among susceptibility polymorphisms for $\mathrm{AD}$, the most recognized is the lipid carrying protein, apolipoprotein E (Apo E) 55, 56. A large neuropathological study investigating the utility of Apo E genotyping found that $\mathrm{Apo} \mathrm{E} \varepsilon 4$ presence increased diagnostic accuracy for $\mathrm{AD}$ by about 4 percent and its absence increased the diagnostic accuracy of something other than AD by 8 percent ${ }^{57}$. These percentages augmented the clinician's diagnostic accuracy. Apo E testing in is not currently recommended for asymptomatic individuals who feel they may be at risk by virtue of a positive family history 56, 58. The American Academy of Neurology does not recommend evaluation of any genetic markers for $\mathrm{AD}$ at this time 4 .

\section{Biomarkers}

Several studies have found that CSF levels of beta amyloid (A $\beta$ ) 1-42 are reduced relative to normal control subjects ${ }^{59-62}$, but the utility of these measurements for early diagnosis remains unclear. Low $A \beta 1-42$ levels were not found to correlate with degree of cognitive impairment 63. A recent study found CSF A $\beta$ 1-42 useful in distinguishing AD with white matter lesions from vascular dementia, with the acknowledgment that $A \beta 1-42$ serves simply as a surrogate marker in this context 64 .

CSF tau levels in AD have been shown to be elevated relative to controls $65-68$. Few studies have compared the CSF A $\beta$ or tau levels to a clinical diagnosis. One study found that in 26 neuropathologically confirmed AD cases, CSF p-tau and brain homogenate p-tau correlated, as did the score of neuritic plaques ${ }^{69}$. The combination of CSF A $\beta$ 1-42 and tau, and in particular the species of tau phosphorylated at threonine 181 or 231 (p-tau), may be useful, and studies have indicated sensitivities and specificities of 85 and 87 percent, respectively 60, 62, 70-72. However, it is not known if these biomarkers augment the diagnostic accuracy of the clinician.

Another CSF marker, AD7c-NTP (neuronal thread protein), has shown high sensitivities and specificities, but due to technical limitations and the absence of studies of well delineated patient populations, the utility of quantitative measurement of this marker in CSF or urine is unclear ${ }^{73-76 .}$

The American Academy of Neurology practice parameter states that no biomarkers have emerged as being appropriate for routine use in the clinical evaluation of patients with suspected $\mathrm{AD}^{4}$.

AD Pathophysiology-Most investigators believe that $\mathrm{AD}$ is all or in part due to abnormal processing or deposition of amyloid. The pathogenic form of amyloid is generated by abnormal cleavage of amyloid precursor protein (APP), and is referred to as A $\beta$ 1-42. Normally, APP is cleaved by $\alpha$-secretase. A $\beta 1-42$ is formed when APP is cleaved by $\beta$ - and $\gamma$-secretases and then deposited in the brain as an insoluble aggregate. This deposition presumably initiates a cascade of events which result in inflammatory responses and cell destruction. While this may not be the only pathologic process, it is believed to be an important component of the degenerative cascade, and is the target for many new treatment interventions.

The other primary pathologic feature of $\mathrm{AD}$ involves the abnormal processing of tau and neurofibrillary tangle formation. The recent development of animal models exhibiting both $\mathrm{A} \beta$ deposition and neurofibrillary tangles holds promise of providing a better model of the fundamental pathological elements involved in human $\mathrm{AD}$. 


\section{MILD COGNITIVE IMPAIRMENT}

\section{A. Conceptual Framework}

Clinicians are faced with the dilemma of trying to determine the importance of a patient's forgetfulness. Elderly individuals who feel that their memory has changed from a previous level of functioning are frequently concerned about developing AD. Mild cognitive impairment (MCI) refers to the clinical state in which a subject is cognitively impaired usually in the memory domain, but not demented.

The American Academy of Neurology practice parameter addressing MCI, concluded that persons with memory impairment who meet criteria for MCI have an increased risk of progressing to clinically probable AD and should be counseled and followed accordingly 5 . Ideally, identification of these individuals would allow an effective treatment intervention to reduce this risk of progression to dementia, but at present no treatment exists that does so. Candidate treatments include cholinesterase inhibitors, antioxidants, anti-inflammatories and nootropics 77 .

\section{B. Clinical Criteria}

While there are no accepted criteria for the diagnosis of MCI, most investigators have used the variation of those presented in Table 3. Longitudinal clinical studies indicate that subjects with amnestic $\mathrm{MCI}$ have an increased rate of progression to clinically probable $\mathrm{AD}^{78}$. It should be emphasized that these criteria for MCI are clinical. While neuropsychological testing may help to differentiate these individuals from those who experience normal aging, $\mathrm{MCI}$ is not a neuropsychological diagnosis. A recent study from France demonstrated the unreliability of retrospective application of a neuropsychological test-based definition of MCI ${ }^{79}$. This study found that application of arbitrary neuropsychological cutoffs in the absence of clinical judgment eliminated the predictive value of the MCI diagnosis. However, diagnosis based upon neuropsychological data used in conjunction with the clinical criteria shown in Table 3 can be reliable and predictive of eventual progression ${ }^{80}$.

The first diagnostic criterion is a cognitive complaint. Typically subjects are mildly affected and are aware of their deficit, and corroboration by an informant is particularly useful ${ }^{81}$. The second criterion requires objective demonstration of cognitive impairment by the clinician and neuropsychologist, relative to their age- and education-mates 82,83 . As discussed, no particular reference point for normal aging is entirely accurate, but normative data on subjects of similar demographic characteristics may be useful. MCI subjects tend to fall 1.5 standard deviations below their age- and education-matched mates on measures of learning and recall, but it must be emphasized that these are only guidelines and not cutoff scores for assisting in the diagnosis of MCI. Some subjects who fall within the normal range of memory function may in fact have experienced a decline from their prior level of function, and it may be appropriate to diagnosis MCI.

The third criterion refers to relatively normal general cognition. Put simply, cognitive domains outside the one primarily impaired are relatively preserved. Close inspection of these subjects may demonstrate subtle deficits in other cognitive domains, but they are not of sufficient severity to suggest that the person is demented ${ }^{80}$. Again, this is a clinical judgment. Similarly, activities of daily living are largely preserved. Subjects may experience minor difficulties due to memory deficits, so technically their activities of daily living are slightly impaired. However, the degree of impairment is insufficient to constitute dementia.

The last criterion is perhaps the most important. The clinician does not feel that the patient meets criteria for dementia or clinically probable AD. These individuals function independently in the community and carry out their routine daily activities. Most clinicians 
feel that it would be a disservice to label these patients with the diagnosis of AD at this very mild stage of impairment, and the concept of MCI has been developed to identify them.

More recently, the construct of MCI has been extended beyond just memory deficit ${ }^{84}$. As shown in Figure 2, the person can now have any type of cognitive complaint, although memory is most common. In the estimation of the clinician, this person is not normal for age but not demented, based upon the clinical history from the patient and an informant and office exam, possibly supplemented with additional cognitive testing. Despite the cognitive decline, activities of daily living remain essentially normal. Patients meeting these criteria merit consideration for the diagnosis of MCI. As Figure 2 illustrates, the major subtypes of $\mathrm{MCI}$ are amnestic MCI or non-amnestic MCI. Memory function is assessed by the mental status exam, which may be supplemented with neuropsychological testing. If memory impairment is present, cognitive testing can help to determine whether only memory is affected (amnestic MCI single domain) or whether other cognitive domains are also impaired (amnestic cognitive impairment-multiple domain). The other cognitive domains typically evaluated include language, attention/executive function and visuospatial skills. If the person meets MCI criteria and memory is not impaired, other cognitive domains need to be assessed to determine if it is an isolated problem (non-amnestic MCI single domain) or if multiple non-memory domains involved (non-amnestic MCI multiple domain).

Similar to the evaluation of the etiology of dementia, the historical and neuroimaging data may suggest the cause of MCI is of a degenerative, vascular, psychiatric, or traumatic etiology or secondary to medical illnesses, as illustrated in Figure 3. In reality, part of the scheme shown in Figure 3 is theoretical and not yet validated, while other aspects are well documented in the literature $85-87$. Amnestic MCI of a degenerative etiology is highly likely to progress to AD and the American Academy of Neurology endorsed this construct in its practice parameter 5 . The corresponding outcome of non-amnestic MCI subjects is currently under investigation.

\section{Evaluation}

The clinical evaluation of suspected MCI is virtually identical to that described above for clinically probable $\mathrm{AD}$. As mentioned, the history is of particular importance and should be verified by an informant, if this is at all possible. The clinician should perform a mental status examination in addition to a general neurologic exam. Most of the commonly used instruments available, MMSE, 3MS, Kokmen Short Test of Mental Status 28, 29, 31, are relatively insensitive in this range of cognitive function, and in all likelihood performance on these measures will appear more normal than not. Subjects with MCI often score in the 26 to 28 range on the MMSE, which is typically reported as normal. If the mental status exam instrument does not have a significant memory component, subjects with relatively isolated memory impairment will not be differentiated from those who are aging normally. Consequently, the clinician may consider augmenting the clinical examination with an additional memory test 88,89 .

The medical laboratory tests are similar to those described above for clinically probable AD as well (Table 2). One should pay particular attention to subtle medical issues that could affect cognitive function. . While depression can often be differentiated from clinically probable AD, it could present with subtle memory impairment in its early stages. Consequently, the clinician should remain attuned to possible psychiatric components of subtle memory impairments as well.

\section{Neuroimaging}

Several recent MRI studies involving volumetric assessments of medial temporal lobe have been informative $33-36,90$. There is ongoing discussion of the relative utility of volumetric 
measurements of the hippocampal formation versus entorhinal cortex volumes 35-37. Measurements of whole brain atrophy are under investigation, although it remains to be determined if whole brain volume changes will be useful in assessing the early stages of AD. A 2001 study suggested that this may be the case 91 and was supported by a subsequent prospective study ${ }^{92}$, although precise delineation of the rate of atrophy in early $\mathrm{AD}$ will require further study.

The utility of other imaging modalities, such as magnetic resonance spectroscopy, SPECT and PET, has not been definitively demonstrated in this population yet ${ }^{93}$. Nevertheless, in selected instances, particularly in the setting of a normal structural imaging scan, functional imaging modalities may provide additional useful information ${ }^{94}$. Patients with amnestic MCI are at an increased risk of progression to $\mathrm{AD}$, and imaging agents such as PIB or FDDNP may augment this prognostic information, although this is not yet verified.

\section{E. Neuropsychological Testing}

Neuropsychological testing can aid in differentiating subjects with MCI from normal aging, but the testing battery must involve sufficiently difficult learning and recall tasks to tease apart these subtle deficits. Neuropsychological testing will not make the diagnosis of MCI, but can be suggestive in the appropriate clinical context 95 . Figure 4 presents typical neurocognitive profiles of subjects with MCI, normal aging and very mild clinically probable Alzheimer's disease (CDR 0.5). On measures of general cognitive function such as the MMSE and full scale IQ, the individual with MCI performs more like the normal elderly subject, while memory function on delayed verbal recall (Logical Memory II) and non-verbal delayed recall (Visual Reproductions II) more closely resembles mild $\mathrm{AD}^{80}$.

\section{F. Biomarkers}

As in Alzheimer's disease, biomarkers are in the early stages of development. There are some indications that the CSF measures of $A \beta$ and tau may be useful at differentiating subjects with MCI from normal aging $60,66,96$. These markers may have utility in predicting progression from $\mathrm{MCI}$ to $\mathrm{AD}^{63,97}$. A multinational study found that baseline CSF levels of tau phosphorylated at theorinine 231, but not total tau protein levels, correlated with cognitive decline and conversion from $\mathrm{MCI}$ to $\mathrm{AD}^{72}$. Another recent study that investigated the utility of CSF concentrations of A $\beta$ 1-42, total tau (T-tau) and tau phosphorylated at threonine 181 (p-tau) in predicting progression from MCI to AD reported a sensitivity of $95 \%$ and specificity of $83 \%$ using the combination of elevated T-tau and lowered $A \beta 1-4298$. This is an exciting area of research, but the present data is insufficient to recommend use of CSF biomarkers in evaluation of MCI.

\section{G. Genetics}

The genetic features of MCI are similar to those of clinically probable AD. There appears to be a higher representation of Apo $\mathrm{E} \varepsilon 4$ carriers in MCI, and some studies suggest that presence of the $\varepsilon 4$ allele may be predict a higher rate of progression 99,100 . However, these data are only weakly positive, and Apo E genotyping is not currently recommended as a diagnostic or prognostic indicator in MCI.

\section{H. Neuropathology}

Several studies have reported on the neuropathology of subjects who died with the clinical classification of MCI 101, 102. Neuropathology in subjects with MCI in the Religious Orders Study was intermediate between the neuropathological changes of normal aging and fully developed $\mathrm{AD}^{101}$. This study also indicated that vascular features were present and suggested that both neurodegenerative and vascular changes may account for the clinical features of MCI. 
Another report from the Nun Study indicated that individuals who were retrospectively classified as having MCI primarily had neuropathologic changes of AD at autopsy 103 . This study found that patients with MCI had significantly more neuritic plaques relative to controls, and that these findings were more similar to those of early $\mathrm{AD}$ than normal aging. However, a study from the Mayo Clinic on MCI demonstrated that subjects had intermediate neuropathologic changes significantly different from both controls and $\mathrm{AD}{ }^{102}$. MCI subjects in this series more closely resembled normal control subjects than $\mathrm{AD}$ subjects, implying that these MCI subjects were diagnosed at an earlier stage in the disease process. Two small neuropathological studies demonstrated neurofibrillary tangle pathology in the nucleus basalis 104 and locus ceruleus 105 in MCI and early AD.

A Washington University study found that when dementia subjects classified as having AD and a Clinical Dementia Rating of 0.5 progressed, $84 \%$ of them had the neuropathologic features of $\mathrm{AD}{ }^{106}$. A Mayo Clinic study of 34 subjects previously diagnosed with MCI who had progressed to dementia demonstrated that while approximately $75 \%$ of these subjects went on to have $\mathrm{AD}$, the other $25 \%$ developed other forms of dementia 107 . Therefore, while amnestic MCI criteria are predictive of developing AD, they are not absolute and when patients are diagnosed at an early stage of impairment, neuropathological features do not correspond to $\mathrm{AD}$ at that point in time.

\section{Summary}

The construct of mild cognitive impairment identifies individuals at increased risk of developing AD. The early identification of these more subtle impairments may allow clinicians to counsel and follow their patients more effectively. Many subjects with amnestic MCI will ultimately progress to probable $\mathrm{AD}$. Identification at this earlier point in the progression may ultimately allow intervention to slow or halt progression. Mild cognitive impairment is an important area for clinical research, and work characterizing the clinical features of these subjects and documenting their outcome is progressing at a rapid rate.

\section{TREATMENTS}

\section{A. Alzheimer's Disease}

1. Symptomatic-Five drugs are approved by the Food and Drug Administration (FDA) for the treatment of clinically probable $\mathrm{AD}$ (Table 4), although only four are commonly used. Three of these four are acetylcholinesterase inhibitors, used in response to research indicating a cholinergic deficit in $\mathrm{AD}{ }^{108}$. Acetylcholine is involved in many aspects of cognition including memory and attention. Cholinergic neurons in the basal forebrain project to many regions of the neocortex and to the medial temporal lobe including the hippocampus.

Anticholinergic drugs, such as scopolamine, can impair learning and recall, reminiscent of the cognitive changes seen in $\mathrm{AD}{ }^{109}$. Choline acetyltransferase, the synthetic enzyme for acetylcholine, is reduced in the brains of subjects with $\mathrm{AD} 110,111$. In the past decade, acetylcholinesterase inhibitors have been shown to be effective at modulating the symptoms of $\mathrm{AD}$ and currently form the mainstay of treatment in clinically probable $\mathrm{AD}$.

The first compound approved was tacrine (Cognex), which led the way for treatment of AD. However, tacrine required four times a day dosing and liver toxicity necessitated regular monitoring of liver enzymes. Newer drugs without these limiting features were introduced, and tacrine is now only rarely used for the treatment of $\mathrm{AD}$.

Donepezil (Aricept) became available in the mid-1990s as the next acetylcholinesterase inhibitor approved by the FDA. It is administered once daily and does not require any laboratory monitoring. It is heavily bound to plasma proteins, and has a half-life of approximately 70 hours. Typically, it is started at $5 \mathrm{mg}$ daily and the dose is increased to $10 \mathrm{mg}$ daily after 4 to 
6 weeks if the drug is well tolerated. The most common side effects include nausea, increased bowel frequency and vomiting. Occasionally patients experience vivid dreaming, which may be reduced by morning administration of the drug. Cholinesterase inhibitors could theoretically influence cardiac rhythm, but this is not commonly encountered in the absence of an underlying disturbance of cardiac conduction. They may also have an effect on respiratory conditions such as chronic obstructive pulmonary disease or asthma and could theoretically interfere with the administration of anesthesia during surgery. The absorption of donepezil is not influenced by food intake.

Several studies of the efficacy of donepezil show a modest improvement in cognitive function as measured by scales such as the Alzheimer's Disease Assessment Scale - Cognitive Subscale (ADAS-Cog) and the Clinician's Interview-Based Impression of Change (CIBIC Plus) ${ }^{6}$. The drug is approved for mild to moderate $\mathrm{AD}$, and the length of the response has been documented up to 52 weeks. It is uncertain if the benefit persists longer than this. Studies indicate that performance of the subject returns to the same as in the untreated state when donepezil is discontinued, suggesting that donepezil has a symptomatic effect on the disease but does not affect the underlying pathophysiologic process.

A large study of donepezil in amnestic MCI found a reduced rate of progression to AD during the first 12 months of the study, but no overall impact on rate of progression at the 3 year endpoint ${ }^{112}$. This suggests a transient symptomatic benefit without modification of disease course in amnestic MCI, similar to its effect in AD.

Rivastigmine (Exelon) is another acetylcholinesterase inhibitor approved by the FDA 113 . Rivastigmine is a pseudo-irreversible inhibitor of acetylcholinesterase and dissociates from the enzyme slowly. Dosing begins with $1.5 \mathrm{mg}$ twice a day and increases in increments of $1.5 \mathrm{mg}$ per dose to a maximum of $6 \mathrm{mg}$ twice daily. While this offers greater dosing flexibility, the twice daily dosing may make it more difficult for memory impaired patients to adhere to therapy. It may provide greater cholinesterase inhibition at the highest dose, but is also prone to an increased frequency of side effects possibly related to its inhibition of

butyrylcholinesterase. Side effects are similar to those of donepezil, although with a somewhat higher incidence of GI side effects 113 . To encourage adherence to dose increases, titration is recommended to be advanced on a 2 to 4 week basis. The effect size of rivastigmine on the ADAS-Cog and the CIBIC Plus is approximately the same as donepezil ${ }^{6}$.

The fourth cholinesterase inhibitor approved by the FDA, galantamine (Reminyl), is a reversible inhibitor of cholinesterase which also has some nicotinic receptor activity. This mechanism has been proposed to provide an additional benefit over the other cholinesterase inhibitors. The initial starting dose of galantamine is $4 \mathrm{mg}$ twice daily, which is increased to 8 $\mathrm{mg}$ twice daily and ultimately $12 \mathrm{mg}$ twice daily if tolerated. This dose escalation is done at four week intervals to minimize side effects. Galantamine has similar potential for GI, cardiac and pulmonary concerns as the other cholinesterase inhibitors. The effect size of galantamine on the ADAS-Cog and the CIBIC Plus is similar to donepezil and rivastigmine. One study found that galantamine had an effect on activities of daily living and behavior ${ }^{114}$. Concern about an increase in mortality, presumably from cardiac deaths, has arisen in clinical trials of galantamine in MCI. The FDA has expressed caution about the use of galantamine for that indication.

Memantine (Namenda) is a NMDA antagonist which has been approved by the FDA for the treatment of moderate to severe AD. This drug can be used either alone or in combination with a cholinesterase inhibitor to help improve the symptoms of $\mathrm{AD}$, but has not been shown to have an effect on the underlying disease process. 
In summary, donepezil, rivastigmine, galantamine and memantine are the most commonly used drugs in the treatment of $\mathrm{AD}$. They appear to be equally efficacious, have a similar side effect profiles, their cost is approximately equivalent and there is little evidence to recommend one over the other. They appear to provide a modest enhancement of cognitive function in subjects with $\mathrm{AD}$ but do not seem to have a significant impact on the underlying pathophysiology of AD. The American Academy of Neurology's practice parameter on treatment of dementia recommended that cholinesterase inhibitors be considered in mild to moderate AD patients, although the effect size is modest 6 . The gastrointestinal side effects can be minimized with slow titration of the drug. Their role in MCI is incompletely defined, with a large trial suggesting transient symptomatic benefit in amnestic MCI, but no lasting impact on progression to $\mathrm{AD}{ }^{112}$.

Cost effectiveness of the cholinesterase inhibitors has been debated with one study suggesting a modest cost savings in favor of donepezil over placebo with a reduction in the use of residential care 115 and another study coming to the opposite conclusion 116 . Comparable studies have not been done with the other cholinesterase inhibitors or with memantine. Thus, the long-term benefit remains questionable from an economic perspective.

\section{Disease Modifying}

a. Vitamin E: Considerable research supports a role of oxidative damage in the pathophysiology of $\mathrm{AD}$, and the use of antioxidants as a treatment of $\mathrm{AD}$ remains an area of active research. Epidemiologic data suggest that anti-oxidants may be associated with a lower incidence of $A D{ }^{117-121}$. A large clinical trial of moderate $A D$ patients found that vitamin $\mathrm{E}$ and selegiline were effective at slowing the progression of moderate $A D{ }^{122}$. The primary endpoint of this study were death, institutionalization, loss of basic activities of daily living or a progression on the CDR from 2 to 3 , and both vitamin $\mathrm{E}$ and selegiline reduced the rate of progression. The dosage of vitamin $\mathrm{E}$ was 1,000 IU twice daily and that of selegiline was 10 $\mathrm{mg}$ daily. Due to its drug interactions and other potential toxicities as well as a suggestion of a very mild superiority of vitamin $\mathrm{E}$ to selegeline, the AAN practice parameter recommended that vitamin $\mathrm{E}$ at $1000 \mathrm{IU}$ twice daily can be considered as a treatment to slow the progression of $\mathrm{AD}^{6}$. This finding has not been replicated, nor has the optimal dose of vitamin $\mathrm{E}$ been determined by additional studies. A single large study which investigated vitamin $E$ in amnestic MCI found no benefit over placebo ${ }^{112}$. Theoretical concerns of GI toxicity and bleeding exist with vitamin $\mathrm{E}$, but generally it is well tolerated.

This single positive study for vitamin E needs to be interpreted in the context of a recent metaanalysis that suggests an increased risk of death among those taking vitamin $\mathrm{E}$ at $400 \mathrm{IU}$ or more per day 123 . These deaths were mostly cardiovascular, and overall medical condition of the participants in the studies pooled for meta-analysis may not accurately represent typical AD patients.

\section{Under Investigation}

a. Anti-inflammatory Medications: Research implicates an inflammatory component to the neurodegenerative process in $\mathrm{AD}^{124}, 125$ and epidemiologic studies have suggested that nonsteroidal anti-inflammatory drug (NSAID) use may protect against developing AD $126-$ 130 . Given this background, it is not surprising that several studies have been undertaken to determine the possible efficacy of anti-inflammatories in treating $\mathrm{AD}{ }^{131-133}$.

Studies using glucocorticoids such as prednisone or NSAIDs have been negative to date 131 , 134. The cyclooxygenase (COX) -2 inhibitors have not been demonstrated to be beneficial and cardiovascular concerns exist regarding the prolonged use of these medications $135-$

139. Thus, while the epidemiologic data and theoretical considerations remain intriguing, the 
benefit of anti-inflammatory agents for the treatment or prevention of $\mathrm{AD}$ has yet to be demonstrated 140 .

There is speculation that some NSAIDs may have specific $A \beta$ lowering properties and hence might be useful in the treatment of AD through an alternative mechanism, and this remains an area of ongoing research ${ }^{141-143}$.

b. Estrogen Replacement Therapy: Some epidemiologic evidence suggests that postmenopausal women who take estrogen replacement may be protected from developing AD 144-147. More recently, the Women's Health Initiative Memory Study has demonstrated that post-menopausal estrogen use might actually be a risk factor for developing AD and MCI rather than a protective factor ${ }^{148-151}$. There are longitudinal studies underway concerning possible prophylactic effect of estrogen in reducing the risk of developing dementia, but the data from these studies are pending 152, 153. A large trial of estrogen replacement in mild to moderate $\mathrm{AD}$ failed to demonstrate benefit over the course of 12 months ${ }^{154}$. A smaller 16-week trial was also negative ${ }^{155}$. A case-control study found no overall correlation between estrogen replacement and incident cases of $\mathrm{AD}$, although it did suggest that this factor interacted with smoking history 156 . At present there are no data which suggest that estrogen is useful as a treatment or prophylactic for $\mathrm{AD}$ and it is currently not recommended for that purpose.

c. Amyloid Treatments: Deposition of beta amyloid $(\mathrm{A} \beta)$ is considered to be intrinsic to the pathophysiology of $\mathrm{AD}$ and several research strategies are underway that address this mechanism ${ }^{157}$. Beta amyloid is a major component of the neuritic plaques in $\mathrm{AD}$, and fibrillar $\mathrm{A} \beta$ has been shown to be neurotoxic. Beta amyloid is processed by several proteases to various amylogenic and non-amylogenic pathways 158 . The protease $\alpha$-secretase produces the nonamylogenic fragments and is the preferred pathway, while $\beta$-secretase and $\gamma$-secretase cleavage results in the generation of $A \beta$. Consequently, strategies which attempt to inhibit the activities of $\beta$-secretase and $\gamma$-secretase have been developed $159-162$. The $\beta$-secretase enzyme BACE is one target 163 and $\gamma$-secretase is another 164-167. A 12 month clinical trial of an NSAIDderived $\gamma$-secretase inhibitor suggested benefit in daily activities and psychiatric events 168 , and a larger phase III trial of this agent is ongoing. Thus, while candidate compounds have been identified, only limited clinical trial data are currently available.

Immunization was proposed as a treatment in 1999, based upon mouse data suggesting that immunization of $A \beta$ in early life reduced $A \beta$ plaque formation later in life ${ }^{169}$. Mid-life immunization of these mice showed a reduced progression of the disease as well as a suggesting some regression of the underlying pathology 169.

A multicenter Phase II clinical trial of active immunotherapy with a vaccine against $A \beta-42$ (AN1792) plus adjuvant QS-21 in humans began in 2001. This study was halted in early 2002 after a subacute meningoencephalitis developed in approximately $5 \%$ of the immunized subjects ${ }^{170}$. Active immunization was discontinued; however there was a suggestion that the subset of subjects who developed sufficient antibody levels may have had a reduced progression of the disease ${ }^{171}$. The few autopsies performed on trial participants have suggested some clearance of neuritic plaques ${ }^{172}$. Subjects who produced antibody showed more brain volume reduction on MRI, hinting that some degree of amyloid clearing process may have affected brain volumes 173 .

Polyclonal antibodies against $A \beta$ can be found in human immunoglobulins, and IVIg has been advanced as a method of passive immunization for the treatment of $\mathrm{AD} 174,175$. One study of five patients suggested that monthly IVIg reduced CSF A $\beta$ concentrations while increasing serum levels of $A \beta^{175}$. A phase I trial of IVIg in eight patients suggested sustained cognitive benefit among some patients 176 and a small phase II trial is currently underway. Passive 
immunization using monoclonal antibodies produced in cell culture has also been proposed, and a phase IIa trial of bapineuzumab (a humanized antibody against $A \beta$ ) is expected to be completed in 2008 .

4. Non-cognitive symptoms-Non-cognitive symptoms of AD such as anxiety, depression, psychosis and sleep disturbances may prove more bothersome to the patient and family than cognitive impairment and can cause considerable stress on both the patient and the caregiver. These non-cognitive symptoms often require ongoing active management by the physician and are the motivating factor for many telephone calls. Many of these symptoms can be ameliorated, and consequently they deserve significant attention on the part of the treating physician. Increased recognition of these non-cognitive symptoms has fostered increasing research attention in this area 177 .

An increased risk of cardiovascular symptoms, glucose intolerance, stroke, and death has been associated with the use atypical antipsychotics in some psychiatric disorders, and this has resulted in an FDA "black box warning" on the use of atypical antipsychotics in older subjects with dementia ${ }^{178}$. Caution should be exercised in using these drugs, but their judicious use can have a dramatically positive impact on problematic behavioral symptoms 6 .

a. Frequency of Symptoms: Estimates of the frequency of non-cognitive symptoms in AD vary from virtually absent to over 80 percent (Table 5) $179-183$. One study using the Neuropsychiatric Inventory (a questionnaire established to assess an array of neuropsychiatric symptoms and their impact as estimated by caregivers), found apathy to be the most common symptom, followed by agitation, anxiety, irritability, dysphoria, disinhibition, delusions, hallucinations and euphoria, respectively 182 . Co-occurrence of non-cognitive symptoms is also common, and the symptom complexes tend to fluctuate. Consequently, treatment strategies require ongoing adjustment.

b. Assessment: It should not be presumed that all non-cognitive symptoms in an AD patients are a result of progression of the underlying neurodegenerative process. Medical problems may manifest as a behavioral change and screening for urinary tract infection, pneumonia, congestive heart failure and electrolyte abnormality should be considered. Treatment of the underlying medical issues may improve or eliminate the problematic behaviors.

c. Behavioral Management: Non-pharmacologic methods should be considered, and can avoid potential side effects of additional medications ${ }^{16}$. Environmental changes such as family crises, new caregivers or altered surroundings may exacerbate or cause behavioral problems. Often, simple strategies such as distraction, redirection or exercise can ameliorate the behaviors.

d. Pharmacologic Treatments: Behaviors of sufficient severity to disrupt a patient's (or caregiver's) quality of life may require pharmacologic intervention. Accurate assessment of the underlying condition is a crucial first step 182 and several scales exist to assist the clinician in addressing these behaviors, including the BEHAVE-AD, 183 the Cohen-Mansfield Agitation Inventory (CMAI) 184 and the Neuropsychiatric Inventory (NPI) ${ }^{185}$. The NPI is one of the most commonly used instruments, and assesses ten commonly encountered behaviors including delusions, hallucinations, agitation, dysphoria, anxiety, apathy, irritability, euphoria, disinhibition and aberrant motor behavior. The frequency and severity of the symptoms are reported by a caregiver, allowing computation of a final index for each behavior. The impact on the caregiver is also assessed. The NPI-Q is an abbreviated version designed for assessment in the office setting 186 . Table 5 shows the frequency of non-cognitive behaviors in $\mathrm{AD}$. 
d. Depression: Depression or dysphoria is common in $\mathrm{AD}$, and can herald the onset of the disorder ${ }^{187}$ or develop as the dementia progresses ${ }^{182}$. It commonly worsens cognitive symptoms and places greater stress on the caregiver. Selective serotonin reuptake inhibitors (SSRIs) are the preferred treatments for depression in AD. Tricyclic antidepressants may also be effective, but anti-cholinergic side effects may worsen cognition and act at cross-purpose to cholinesterase inhibitors (Table 6).

f. Psychosis: Delusions are common in AD, often with coexistent paranoia 188, 189 . Hallucinations can be seen in $\mathrm{AD}$, particularly if Lewy bodies are present, and misidentification syndromes can occur when the right hemisphere is predominantly involved. Psychosis can also indicate a more rapid decline in function 15,190 .

Non-pharmacologic interventions are the preferable first-line treatment for psychosis, agitation, aggression and other problematic behaviors which may compromise the health and safety of patients and those around them. Atypical anti-psychotic medications remain the preferred treatment of psychosis in AD. Risperidone was demonstrated to improve psychosis and aggression, but did produce somnolence and extrapyramidal symptoms ${ }^{191}$. Quetiapine has been shown to reduce psychotic symptoms with relatively few side effects 192 , as has olanzapine ${ }^{193}$. The results of the CATIE-AD trial generated significant publicity in suggesting that potential adverse effects of atypical antipsychotics may offset potential benefits from these agents 194 . A subsequent meta-analysis of placebo-controlled trials of atypical neuroleptic medications found only modest group efficacy and echoed concerns about potential adverse effects ${ }^{195}$. In this analysis, the authors recommend that deliberate consideration and discussion with patients and their families should precede initiation of antipsychotic medications. These medications should be discontinued if improvement has not been seen within 10-12 weeks and should be adjusted to the minimum effective dosage. Periodic medication withdrawal trials may be used to evaluate for continued necessity. These authors also caution against the imprudence of prescribing alternative medications as first-line agents due to a perception that they are safer or as effective as antipsychotics. Atypical antipsychotics can be expensive, but are generally felt to be preferable to typical anti-psychotic agents such as haloperidol (Table 6).

g. Apathy: Apathy may be the most common non-cognitive symptoms in $\mathrm{AD}$ 177, 182 and causes diminished quality of life for both patient and caregiver. Acetylcholinesterase inhibitors may be useful, but pharmacological management of these symptoms is not well developed. Other medications such as methylphenidate, bromocriptine, pramipexole, ropinerole or activating anti-depressants such as fluoxetine may theoretically be useful, although benefit has not been established in the literature 196 .

h. Agitation: Agitation can be quite bothersome to caregivers since the patient appears to be in distress ${ }^{197}$. Trazodone can useful, and has a better side effect profile than haloperidol 198. Atypical anti-psychotic agents such as risperidone, olanzapine and quetiapine can be considered, as can anti-convulsants such as carbamazepine or valproic acid 199, 200.

i. Summary: Non-cognitive symptoms of AD can be responsible for significant distress for both patients and caregivers, and their impact can be ameliorated using both pharmacologic and behavioral interventions. Interventions are being studied more extensively, with the recognition that successful intervention can result in significant improvement of the qualities of lives for all involved. 


\section{Acknowledgements}

We would like to acknowledge the support for preparation of this chapter and research reported herein from the National Institute on Aging P50 AG16574, U01 AG06786, and the Robert H. and Clarice Smith and Abigail van Buren Alzheimer's Disease Research Program.

\section{References}

1. Brookmeyer R, Gray S, Kawas C. Projections of Alzheimer's disease in the United States and the public health impact of delaying disease onset. Am J Public Health Sep;1998 88(9):1337-1342. [PubMed: 9736873]

2. Petersen RC. Aging, mild cognitive impairment, and Alzheimer's disease. Neurol Clin Nov;2000 18 (4):789-806. [PubMed: 11072261]

3. Petersen, RC. Mild Cognitive Impairment: Transtion from Aging to Alzheimer's Disease. In: Iqbal, KSS.; Winblad, B., editors. Alzheimer's Disease: Advances in Etiology, Pathogenesis and Therapeutics. West Sussex, England: J Wiley \& Sons, Ltd; 2001. p. 141-151.

4. Knopman DS, DeKosky ST, Cummings JL, et al. Practice parameter: diagnosis of dementia (an evidence-based review). Report of the Quality Standards Subcommittee of the American Academy of Neurology. Neurology May 8;2001 56(9):1143-1153. [PubMed: 11342678]

5. Petersen RC, Stevens JC, Ganguli M, Tangalos EG, Cummings JL, DeKosky ST. Practice parameter: early detection of dementia: mild cognitive impairment (an evidence-based review). Report of the Quality Standards Subcommittee of the American Academy of Neurology. Neurology May 8;2001 56 (9):1133-1142. [PubMed: 11342677]

6. Doody RS, Stevens JC, Beck C, et al. Practice parameter: management of dementia (an evidence-based review). Report of the Quality Standards Subcommittee of the American Academy of Neurology. Neurology May 8;2001 56(9):1154-1166. [PubMed: 11342679]

7. Ivnik RJ, Smith GE, Lucas JA, et al. Testing normal older people three or four times at 1- to 2-year intervals: defining normal variance. Neuropsychology Jan;1999 13(1):121-127. [PubMed: 10067783]

8. Petersen, RC. Mild cognitive impairment: aging to Alzheimer's disease. Oxford; New York: Oxford University Press; 2003.

9. Sliwinski M, Lipton RB, Buschke H, Stewart W. The effects of preclinical dementia on estimates of normal cognitive functioning in aging. J Gerontol B Psychol Sci Soc Sci Jul;1996 51(4):P217-225. [PubMed: 8673642]

10. Backman L, Jones S, Berger AK, Laukka EJ, Small BJ. Cognitive impairment in preclinical Alzheimer's disease: a meta-analysis. Neuropsychology Jul;2005 19(4):520-531. [PubMed: 16060827]

11. aaa. American Psychiatric Association: Diagnostic and Statistical Manual of Mental Disorders. Vol. 3. Washington, DC: American Psychiatric Association; 1987.

12. Fleming KC, Adams AC, Petersen RC. Dementia: diagnosis and evaluation. Mayo Clin Proc Nov; 1995 70(11):1093-1107. [PubMed: 7475341]

13. Burns A, Jacoby R, Levy R. Psychiatric phenomena in Alzheimer's disease. IV: Disorders of behaviour. Br J Psychiatry Jul;1990 157:86-94. [PubMed: 2397368]

14. Drevets WC, Rubin EH. Psychotic symptoms and the longitudinal course of senile dementia of the Alzheimer type. Biol Psychiatry Jan;1989 25(1):39-48. [PubMed: 2912509]

15. Rosen J, Zubenko GS. Emergence of psychosis and depression in the longitudinal evaluation of Alzheimer's disease. Biol Psychiatry Feb 1;1991 29(3):224-232. [PubMed: 2015329]

16. Teri L, Larson EB, Reifler BV. Behavioral disturbance in dementia of the Alzheimer's type. J Am Geriatr Soc Jan;1988 36(1):1-6. [PubMed: 3335725]

17. The National Institute on Aging, and Reagan Institute Working Group on Diagnostic Criteria for the Neuropathological Assessment of Alzheimer's Disease. Consensus recommendations for the postmortem diagnosis of Alzheimer's disease. Neurobiol Aging Jul-Aug;1997 18(4 Suppl):S1-2. [PubMed: 9330978]

18. Kukull WA, Ganguli M. Epidemiology of dementia: concepts and overview. Neurol Clin Nov;2000 18(4):923-950. [PubMed: 11072268] 
19. Bachman DL, Wolf PA, Linn R, et al. Prevalence of dementia and probable senile dementia of the Alzheimer type in the Framingham Study. Neurology Jan;1992 42(1):115-119. [PubMed: 1734291]

20. Canadian study of health and aging: study methods and prevalence of dementia. Cmaj Mar 15;1994 150(6):899-913. [PubMed: 8131123]

21. Evans DA, Funkenstein HH, Albert MS, et al. Prevalence of Alzheimer's disease in a community population of older persons. Higher than previously reported. Jama Nov 10;1989 262(18):25512556. [PubMed: 2810583]

22. Hendrie HC, Osuntokun BO, Hall KS, et al. Prevalence of Alzheimer's disease and dementia in two communities: Nigerian Africans and African Americans. Am J Psychiatry Oct;1995 152(10):14851492. [PubMed: 7573588]

23. Hofman A, Ott A, Breteler MM, et al. Atherosclerosis, apolipoprotein E, and prevalence of dementia and Alzheimer's disease in the Rotterdam Study. Lancet Jan 18;1997 349(9046):151-154. [PubMed: 9111537]

24. Kokmen E, Beard CM, Offord KP, Kurland LT. Prevalence of medically diagnosed dementia in a defined United States population: Rochester, Minnesota, January 1, 1975. Neurology Jun;1989 39 (6):773-776. [PubMed: 2725870]

25. White L, Petrovitch H, Ross GW, et al. Prevalence of dementia in older Japanese-American men in Hawaii: The Honolulu-Asia Aging Study. Jama Sep 25;1996 276(12):955-960. [PubMed: 8805729]

26. aaa-apa. Diagnostic and Statistical Manual of Mental Disorders, Fourth Edition, Text Revision (DSMIV-TR). Washington DC: American Psychiatric Association; 2000.

27. McKhann G, Drachman D, Folstein M, Katzman R, Price D, Stadlan EM. Clinical diagnosis of Alzheimer's disease: report of the NINCDS-ADRDA Work Group under the auspices of Department of Health and Human Services Task Force on Alzheimer's Disease. Neurology Jul;1984 34(7):939_ 944. [PubMed: 6610841]

28. Folstein M, Folstein S, McHugh P. "Mini-mental state". A practical method for grading the cognitive state of patients for the clinician. J Psychiatr Res 1975;12:189-198. [PubMed: 1202204]

29. Teng EL, Chui HC. The Modified Mini-Mental State (3MS) examination. J Clin Psychiatry Aug; 1987 48(8):314-318. [PubMed: 3611032]

30. Katzman R, Brown T, Fuld P, Peck A, Schechter R, Schimmel H. Validation of a short OrientationMemory-Concentration Test of cognitive impairment. Am J Psychiatry Jun;1983 140(6):734-739. [PubMed: 6846631]

31. Kokmen E, Smith GE, Petersen RC, Tangalos E, Ivnik RC. The short test of mental status. Correlations with standardized psychometric testing. Arch Neurol Jul;1991 48(7):725-728. [PubMed: 1859300]

32. Morris JC. The Clinical Dementia Rating (CDR): current version and scoring rules. Neurology Nov; 1993 43(11):2412-2414. [PubMed: 8232972]

33. Jack CR Jr, Petersen RC, Xu YC, et al. Medial temporal atrophy on MRI in normal aging and very mild Alzheimer's disease. Neurology Sep;1997 49(3):786-794. [PubMed: 9305341]

34. Jack CR Jr, Petersen RC, Xu YC, et al. Prediction of AD with MRI-based hippocampal volume in mild cognitive impairment. Neurology Apr 22;1999 52(7):1397-1403. [PubMed: 10227624]

35. Killiany RJ, Gomez-Isla T, Moss M, et al. Use of structural magnetic resonance imaging to predict who will get Alzheimer's disease. Ann Neurol Apr;2000 47(4):430-439. [PubMed: 10762153]

36. Xu Y, Jack CR Jr, O'Brien PC, et al. Usefulness of MRI measures of entorhinal cortex versus hippocampus in AD. Neurology May 9;2000 54(9):1760-1767. [PubMed: 10802781]

37. Wahlund LO, Almkvist O, Blennow K, et al. Evidence-based evaluation of magnetic resonance imaging as a diagnostic tool in dementia workup. Top Magn Reson Imaging Dec;2005 16(6):427437. [PubMed: 17088692]

38. Ramani A, Jensen JH, Helpern JA. Quantitative MR imaging in Alzheimer disease. Radiology Oct; 2006 241(1):26-44. [PubMed: 16990669]

39. Van Gool WA, Walstra GJ, Teunisse S, Van der Zant FM, Weinstein HC, Van Royen EA. Diagnosing Alzheimer's disease in elderly, mildly demented patients: the impact of routine single photon emission computed tomography. J Neurol Jun;1995 242(6):401-405. [PubMed: 7561970]

40. Claus JJ, van Harskamp F, Breteler MM, et al. The diagnostic value of SPECT with Tc 99m HMPAO in Alzheimer's disease: a population-based study. Neurology Mar;1994 44(3 Pt 1):454-461. [PubMed: 8145915] 
41. Johnson KA, Kijewski MF, Becker JA, Garada B, Satlin A, Holman BL. Quantitative brain SPECT in Alzheimer's disease and normal aging. J Nucl Med Nov;1993 34(11):2044-2048. [PubMed: 8229257]

42. Johnson KA, Holman BL, Rosen TJ, Nagel JS, English RJ, Growdon JH. Iofetamine I 123 single photon emission computed tomography is accurate in the diagnosis of Alzheimer's disease. Arch Intern Med Apr;1990 150(4):752-756. [PubMed: 2327836]

43. Bartenstein P, Minoshima S, Hirsch C, et al. Quantitative assessment of cerebral blood flow in patients with Alzheimer's disease by SPECT. J Nucl Med Jul;1997 38(7):1095-1101. [PubMed: 9225797]

44. Mielke R, Heiss WD. Positron emission tomography for diagnosis of Alzheimer's disease and vascular dementia. J Neural Transm Suppl 1998;53:237-250. [PubMed: 9700661]

45. Silverman DH, Small GW, Chang CY, et al. Positron emission tomography in evaluation of dementia: Regional brain metabolism and long-term outcome. Jama Nov 7;2001 286(17):2120-2127. [PubMed: 11694153]

46. Kantarci K, Jack CR Jr, Xu YC, et al. Regional metabolic patterns in mild cognitive impairment and Alzheimer's disease: A 1H MRS study. Neurology Jul 25;2000 55(2):210-217. [PubMed: 10908893]

47. Kantarci K, Petersen RC, Boeve BF, et al. 1H MR spectroscopy in common dementias. Neurology Oct 26;2004 63(8):1393-1398. [PubMed: 15505154]

48. Klunk WE, Engler H, Nordberg A, et al. Imaging brain amyloid in Alzheimer's disease with Pittsburgh Compound-B. Ann Neuro Mar;2004 55(3):306-319.

49. Shoghi-Jadid K, Small GW, Agdeppa ED, et al. Localization of neurofibrillary tangles and betaamyloid plaques in the brains of living patients with Alzheimer disease. Am J Geriatr Psychiatry Jan-Feb;2002 10(1):24-35. [PubMed: 11790632]

50. Small GW, Kepe V, Ercoli LM, et al. PET of brain amyloid and tau in mild cognitive impairment. N Engl J Med Dec 21;2006 355(25):2652-2663. [PubMed: 17182990]

51. Nordberg A. PET imaging of amyloid in Alzheimer's disease. Lancet Neurol Sep;2004 3(9):519_ 527. [PubMed: 15324720]

52. Johnson KA. Amyloid imaging of Alzheimer's disease using Pittsburgh Compound B. Curr Neurol Neurosci Rep Nov;2006 6(6):496-503. [PubMed: 17074285]

53. Becker PM, Feussner JR, Mulrow CD, Williams BC, Vokaty KA. The role of lumbar puncture in the evaluation of dementia: the Durham Veterans Administration/Duke University Study. J Am Geriatr Soc Jun;1985 33(6):392-396. [PubMed: 3889117]

54. Hardy J, Gwinn-Hardy K. Genetic classification of primary neurodegenerative disease. Science Nov 6;1998 282(5391):1075-1079. [PubMed: 9804538]

55. Roses, AD. Apolipoprotein E and Alzheimer's disease. In: Rosenberg, RN.; Prusiner, SB.; DiMaur, oS; Barchi, RL., editors. The Molecular and Genetic Basis of Neurological Disease. Vol. 2. Boston: Butterworth-Heinemann; 1997.

56. Farrer LA, Cupples LA, Haines JL, et al. Effects of age, sex, and ethnicity on the association between apolipoprotein E genotype and Alzheimer disease. A meta-analysis. APOE and Alzheimer Disease Meta Analysis Consortium. Jama Oct 22-29;1997 278(16):1349-1356. [PubMed: 9343467]

57. Mayeux R, Saunders AM, Shea S, et al. Utility of the apolipoprotein E genotype in the diagnosis of Alzheimer's disease. Alzheimer's Disease Centers Consortium on Apolipoprotein E and Alzheimer's Disease. N Engl J Med Feb 19;1998 338(8):506-511. [PubMed: 9468467]

58. Roses, AD. The predictive value of APOE genotyping in the early diagnosis of dementia of the Alzheimer type: Data from three independent series. In: Iqbal, K.; Winblad, B.; Nishimura, T.; Takeda, M.; Wisniewski, HM., editors. Alzheimer's Disease: Biology, Diagnosis and Therapeutics. West Sussex, England: John Wiley \& Sons; 1997. p. 85-91.

59. Andreasen N, Hesse C, Davidsson P, et al. Cerebrospinal fluid beta-amyloid(1-42) in Alzheimer disease: differences between early- and late-onset Alzheimer disease and stability during the course of disease. Arch Neurol Jun;1999 56(6):673-680. [PubMed: 10369305]

60. Galasko D, Chang L, Motter R, et al. High cerebrospinal fluid tau and low amyloid beta42 levels in the clinical diagnosis of Alzheimer disease and relation to apolipoprotein E genotype. Arch Neurol Jul;1998 55(7):937-945. [PubMed: 9678311]

61. Hulstaert F, Blennow K, Ivanoiu A, et al. Improved discrimination of AD patients using beta-amyloid (1-42) and tau levels in CSF. Neurology May 12;1999 52(8):1555-1562. [PubMed: 10331678] 
62. Shoji M, Matsubara E, Kanai M, et al. Combination assay of CSF tau, A beta 1-40 and A beta 1-42 (43) as a biochemical marker of Alzheimer's disease. J Neurol Sci Jun 30;1998 158(2):134-140. [PubMed: 9702683]

63. Stefani A, Martorana A, Bernardini S, et al. CSF markers in Alzheimer disease patients are not related to the different degree of cognitive impairment. J Neurol Sci Dec 21;2006 251(1-2):124-128. [PubMed: 17097109]

64. Stenset V, Johnsen L, Kocot D, et al. Associations between white matter lesions, cerebrovascular risk factors, and low CSF Abeta42. Neurology Sep 12;2006 67(5):830-833. [PubMed: 16966546]

65. Arai H, Higuchi S, Sasaki H. Apolipoprotein E genotyping and cerebrospinal fluid tau protein: implications for the clinical diagnosis of Alzheimer's disease. Gerontology 1997;43 (Suppl 1):2-10. [PubMed: 9187933]

66. Galasko D, Clark C, Chang L, et al. Assessment of CSF levels of tau protein in mildly demented patients with Alzheimer's disease. Neurology Mar;1997 48(3):632-635. [PubMed: 9065538]

67. Kurz A, Riemenschneider M, Buch K, et al. Tau protein in cerebrospinal fluid is significantly increased at the earliest clinical stage of Alzheimer disease. Alzheimer Dis Assoc Disord Dec;1998 12(4):372-377. [PubMed: 9876968]

68. Andreasen N, Minthon L, Clarberg A, et al. Sensitivity, specificity, and stability of CSF-tau in AD in a community-based patient sample. Neurology Oct 22;1999 53(7):1488-1494. [PubMed: 10534256]

69. Buerger K, Ewers M, Pirttila T, et al. CSF phosphorylated tau protein correlates with neocortical neurofibrillary pathology in Alzheimer's disease. Brain Nov;2006 129(Pt 11):3035-3041. [PubMed: 17012293]

70. Clark CM, Xie S, Chittams J, et al. Cerebrospinal fluid tau and beta-amyloid: how well do these biomarkers reflect autopsy-confirmed dementia diagnoses? Arch Neurol Dec;2003 60(12):16961702. [PubMed: 14676043]

71. Schoonenboom NS, Pijnenburg YA, Mulder C, et al. Amyloid beta(1-42) and phosphorylated tau in CSF as markers for early-onset Alzheimer disease. Neurology May 11;2004 62(9):1580-1584. [PubMed: 15136685]

72. Buerger K, Teipel SJ, Zinkowski R, et al. CSF tau protein phosphorylated at threonine 231 correlates with cognitive decline in MCI subjects. Neurology Aug 27;2002 59(4):627-629. [PubMed: 12196665]

73. de la Monte SM, Volicer L, Hauser SL, Wands JR. Increased levels of neuronal thread protein in cerebrospinal fluid of patients with Alzheimer's disease. Ann Neurol Dec;1992 32(6):733-742. [PubMed: 1471863]

74. de la Monte SM, Wands JR. The AD7c-ntp neuronal thread protein biomarker for detecting Alzheimer's disease. Front Biosci Apr 1;2002 7:d989-996. [PubMed: 11897561]

75. Monte SM, Ghanbari K, Frey WH, et al. Characterization of the AD7C-NTP cDNA expression in Alzheimer's disease and measurement of a $41-\mathrm{kD}$ protein in cerebrospinal fluid. J Clin Invest Dec 15;1997 100(12):3093-3104. [PubMed: 9399956]

76. Ghanbari K, Ghanbari HA. A sandwich enzyme immunoassay for measuring AD7C-NTP as an Alzheimer's disease marker: AD7C test. J Clin Lab Anal 1998;12(4):223-226. [PubMed: 9671174]

77. Geda, YE.; Petersen, RC. Clinical trials in mild cognitive impairment. In: Gauthier, S.; Cummings, JL., editors. Alzheimer's Disease and Related Disorders Annual 2001. Vol. 103. London: Martin Dunitz; 2001. p. 69-83.

78. Petersen RC, Doody R, Kurz A, et al. Current concepts in mild cognitive impairment. Arch Neurol Dec;2001 58(12):1985-1992. [PubMed: 11735772]

79. Ritchie K, Artero S, Touchon J. Classification criteria for mild cognitive impairment: a populationbased validation study. Neurology Jan 9;2001 56(1):37-42. [PubMed: 11148233]

80. Petersen RC, Smith GE, Waring SC, Ivnik RJ, Tangalos EG, Kokmen E. Mild cognitive impairment: clinical characterization and outcome. Arch Neurol Mar;1999 56(3):303-308. [PubMed: 10190820]

81. Daly E, Zaitchik D, Copeland M, Schmahmann J, Gunther J, Albert M. Predicting conversion to Alzheimer disease using standardized clinical information. Arch Neurol May;2000 57(5):675-680. [PubMed: 10815133] 
82. Smith GE, Petersen RC, Parisi JE, Ivnik RJ, Tangalos E, Waring S. Definition, course, and outcome of mild cognitive impairment. Aging Neuropsychology \& Cognition 1996;3(2):141-147.

83. Ivnik RJ, Malec JF, Smith GE, et al. Mayo's Older Americans Normative Studies: WAIS-R, WMSR and AVLT norms for ages 56 to 97. Clin Neuropsychol 1992;6(Suppl):1-104.

84. Petersen RC. Mild cognitive impairment as a diagnostic entity. J Intern Med Sep;2004 256(3):183194. [PubMed: 15324362]

85. Bennett DA, Wilson RS, Schneider JA, et al. Natural history of mild cognitive impairment in older persons. Neurology Jul 23;2002 59(2):198-205. [PubMed: 12136057]

86. Ganguli M, Dodge HH, Shen C, DeKosky ST. Mild cognitive impairment, amnestic type: an epidemiologic study. Neurology Jul 13;2004 63(1):115-121. [PubMed: 15249620]

87. Lopez OL, Jagust WJ, DeKosky ST, et al. Prevalence and classification of mild cognitive impairment in the Cardiovascular Health Study Cognition Study: part 1. Arch Neurol Oct;2003 60(10):13851389. [PubMed: 14568808]

88. Knopman DS, Ryberg S. A verbal memory test with high predictive accuracy for dementia of the Alzheimer type. Arch Neurol Feb;1989 46(2):141-145. [PubMed: 2916953]

89. Petersen, RC. Memory assessment at the bedside. In: Yanagihara, TRCP., editor. Memory Disorders. New York: Dekker; 1991. p. 137-152.

90. Fox NC, Warrington EK, Freeborough PA, et al. Presymptomatic hippocampal atrophy in Alzheimer's disease. A longitudinal MRI study. Brain Dec;1996 119 (Pt 6):2001-2007. [PubMed: 9010004]

91. Fox NC, Crum WR, Scahill RI, Stevens JM, Janssen JC, Rossor MN. Imaging of onset and progression of Alzheimer's disease with voxel-compression mapping of serial magnetic resonance images. Lancet Jul 21;2001 358(9277):201-205. [PubMed: 11476837]

92. Schott JM, Price SL, Frost C, Whitwell JL, Rossor MN, Fox NC. Measuring atrophy in Alzheimer disease: a serial MRI study over 6 and 12 months. Neurology Jul 12;2005 65(1):119-124. [PubMed: 16009896]

93. Small GW, Mazziotta JC, Collins MT, et al. Apolipoprotein E type 4 allele and cerebral glucose metabolism in relatives at risk for familial Alzheimer disease. Jama Mar 22-29;1995 273(12):942947. [PubMed: 7884953]

94. Reiman EM, Caselli RJ, Yun LS, et al. Preclinical evidence of Alzheimer's disease in persons homozygous for the epsilon 4 allele for apolipoprotein E. N Engl J Med Mar 21;1996 334(12):752758. [PubMed: 8592548]

95. Petersen RC. Mild cognitive impairment: transition between aging and Alzheimer's disease. Neurologia Mar;2000 15(3):93-101. [PubMed: 10846869]

96. Growdon JH. Biomarkers of Alzheimer disease. Arch Neurol Mar;1999 56(3):281-283. [PubMed: 10190817]

97. Sunderland T, Wolozin B, Galasko D, et al. Longitudinal stability of CSF tau levels in Alzheimer patients. Biol Psychiatry Sep 15;1999 46(6):750-755. [PubMed: 10494442]

98. Hansson O, Zetterberg H, Buchhave P, Londos E, Blennow K, Minthon L. Association between CSF biomarkers and incipient Alzheimer's disease in patients with mild cognitive impairment: a followup study. Lancet Neurol Mar;2006 5(3):228-234. [PubMed: 16488378]

99. Petersen RC, Smith GE, Ivnik RJ, et al. Apolipoprotein E status as a predictor of the development of Alzheimer's disease in memory-impaired individuals. Jama Apr 26;1995 273(16):1274-1278.

[PubMed: 7646655]

100. Tierney MC, Szalai JP, Snow WG, et al. A prospective study of the clinical utility of ApoE genotype in the prediction of outcome in patients with memory impairment. Neurology Jan;1996 46(1):149_ 154. [PubMed: 8559365]

101. Bennett DA, Schneider JA, Bienias JL, Evans DA, Wilson RS. Mild cognitive impairment is related to Alzheimer disease pathology and cerebral infarctions. Neurology Mar 8;2005 64(5):834-841. [PubMed: 15753419]

102. Petersen RC, Parisi JE, Dickson DW, et al. Neuropathologic features of amnestic mild cognitive impairment. Arch Neurol May;2006 63(5):665-672. [PubMed: 16682536] 
103. Riley KP, Snowdon DA, Markesbery WR. Alzheimer's neurofibrillary pathology and the spectrum of cognitive function: findings from the Nun Study. Ann Neurol May;2002 51(5):567-577. [PubMed: 12112102]

104. Mesulam M, Shaw P, Mash D, Weintraub S. Cholinergic nucleus basalis tauopathy emerges early in the aging-MCI-AD continuum. Ann Neurol Jun;2004 55(6):815-828. [PubMed: 15174015]

105. Grudzien A, Shaw P, Weintraub S, Bigio E, Mash DC, Mesulam MM. Locus coeruleus neurofibrillary degeneration in aging, mild cognitive impairment and early Alzheimer's disease. Neurobiol Aging. Mar 27;2006

106. Morris JC, Storandt M, Miller JP, et al. Mild cognitive impairment represents early-stage Alzheimer disease. Arch Neurol Mar;2001 58(3):397-405. [PubMed: 11255443]

107. Jicha GA, Parisi JE, Dickson DW, et al. Neuropathologic outcome of mild cognitive impairment following progression to clinical dementia. Arch Neurol May;2006 63(5):674-681. [PubMed: 16682537]

108. Whitehouse PJ, Price DL, Clark AW, Coyle JT, DeLong MR. Alzheimer disease: evidence for selective loss of cholinergic neurons in the nucleus basalis. Ann Neurol Aug;1981 10(2):122-126. [PubMed: 7283399]

109. Petersen RC. Scopolamine induced learning failures in man. Psychopharmacology (Berl) May 9;1977 52(3):283-289. [PubMed: 406632]

110. Bowen DM, Smith CB, White P, Davison AN. Neurotransmitter-related enzymes and indices of hypoxia in senile dementia and other abiotrophies. Brain Sep;1976 99(3):459-496. [PubMed: 11871]

111. Davies P, Maloney AJ. Selective loss of central cholinergic neurons in Alzheimer's disease. Lancet Dec 25;1976 2(8000):1403. [PubMed: 63862]

112. Petersen RC, Thomas RG, Grundman M, et al. Vitamin E and donepezil for the treatment of mild cognitive impairment. N Engl J Med Jun 9;2005 352(23):2379-2388. [PubMed: 15829527]

113. Rosler M, Anand R, Cicin-Sain A, et al. Efficacy and safety of rivastigmine in patients with Alzheimer's disease: international randomised controlled trial. Bmj Mar 6;1999 318(7184):633638. [PubMed: 10066203]

114. Tariot PN, Solomon PR, Morris JC, Kershaw P, Lilienfeld S, Ding C. A 5-month, randomized, placebo-controlled trial of galantamine in AD. The Galantamine USA-10 Study Group. Neurology Jun 27;2000 54(12):2269-2276. [PubMed: 10881251]

115. Feldman H, Gauthier S, Hecker J, et al. Economic evaluation of donepezil in moderate to severe Alzheimer disease. Neurology Aug 24;2004 63(4):644-650. [PubMed: 15326236]

116. Courtney C, Farrell D, Gray R, et al. Long-term donepezil treatment in 565 patients with Alzheimer's disease (AD2000): randomised double-blind trial. Lancet Jun 26;2004 363(9427):2105-2115. [PubMed: 15220031]

117. Gale CR, Martyn CN, Cooper C. Cognitive impairment and mortality in a cohort of elderly people. Bmj Mar 9;1996 312(7031):608-611. [PubMed: 8595334]

118. Goodwin JS, Goodwin JM, Garry PJ. Association between nutritional status and cognitive functioning in a healthy elderly population. Jama Jun 3;1983 249(21):2917-2921. [PubMed: 6842805]

119. La Rue A, Koehler KM, Wayne SJ, Chiulli SJ, Haaland KY, Garry PJ. Nutritional status and cognitive functioning in a normally aging sample: a 6-y reassessment. Am J Clin Nutr Jan;1997 65 (1):20-29. [PubMed: 8988908]

120. Morris MC, Beckett LA, Scherr PA, et al. Vitamin E and vitamin C supplement use and risk of incident Alzheimer disease. Alzheimer Dis Assoc Disord Sep;1998 12(3):121-126. [PubMed: 9772012]

121. Perrig WJ, Perrig P, Stahelin HB. The relation between antioxidants and memory performance in the old and very old. J Am Geriatr Soc Jun;1997 45(6):718-724. [PubMed: 9180666]

122. Sano M, Ernesto C, Thomas RG, et al. A controlled trial of selegiline, alpha-tocopherol, or both as treatment for Alzheimer's disease. The Alzheimer's Disease Cooperative Study. N Engl J Med Apr 24;1997 336(17):1216-1222. [PubMed: 9110909] 
123. Miller ER 3rd, Pastor-Barriuso R, Dalal D, Riemersma RA, Appel LJ, Guallar E. Meta-analysis: high-dosage vitamin E supplementation may increase all-cause mortality. Ann Intern Med Jan 4;2005 142(1):37-46. [PubMed: 15537682]

124. Aisen PS, Davis KL. Inflammatory mechanisms in Alzheimer's disease: implications for therapy. Am J Psychiatry Aug;1994 151(8):1105-1113. [PubMed: 7518651]

125. McGeer PL, Rogers J. Anti-inflammatory agents as a therapeutic approach to Alzheimer's disease. Neurology Feb;1992 42(2):447-449. [PubMed: 1736183]

126. Andersen K, Launer LJ, Ott A, Hoes AW, Breteler MM, Hofman A. Do nonsteroidal antiinflammatory drugs decrease the risk for Alzheimer's disease? The Rotterdam Study. Neurology Aug;1995 45(8):1441-1445. [PubMed: 7644037]

127. Breitner JC, Welsh KA, Helms MJ, et al. Delayed onset of Alzheimer's disease with nonsteroidal anti-inflammatory and histamine H2 blocking drugs. Neurobiol Aging Jul-Aug;1995 16(4):523530. [PubMed: 8544901]

128. Breitner JC, Gau BA, Welsh KA, et al. Inverse association of anti-inflammatory treatments and Alzheimer's disease: initial results of a co-twin control study. Neurology Feb;1994 44(2):227-232. [PubMed: 8309563]

129. The Canadian Study of Health and Aging: risk factors for Alzheimer's disease in Canada. Neurology Nov;1994 44(11):2073-2080. [PubMed: 7969962]

130. Stewart WF, Kawas C, Corrada M, Metter EJ. Risk of Alzheimer's disease and duration of NSAID use. Neurology Mar;1997 48(3):626-632. [PubMed: 9065537]

131. Aisen PS, Davis KL, Berg JD, et al. A randomized controlled trial of prednisone in Alzheimer's disease. Alzheimer's Disease Cooperative Study. Neurology Feb 8;2000 54(3):588-593. [PubMed: 10680787]

132. Rogers J, Kirby LC, Hempelman SR, et al. Clinical trial of indomethacin in Alzheimer's disease. Neurology Aug;1993 43(8):1609-1611. [PubMed: 8351023]

133. Scharf S, Mander A, Ugoni A, Vajda F, Christophidis N. A double-blind, placebo-controlled trial of diclofenac/misoprostol in Alzheimer's disease. Neurology Jul 13;1999 53(1):197-201. [PubMed: 10408559]

134. Aisen PS, Schafer KA, Grundman M, et al. Effects of rofecoxib or naproxen vs placebo on Alzheimer disease progression: a randomized controlled trial. Jama Jun 4;2003 289(21):2819-2826. [PubMed: 12783912]

135. Ho L, Pieroni C, Winger D, Purohit DP, Aisen PS, Pasinetti GM. Regional distribution of cyclooxygenase-2 in the hippocampal formation in Alzheimer's disease. J Neurosci Res Aug 1;1999 57(3):295-303. [PubMed: 10412020]

136. Pasinetti GM, Aisen PS. Cyclooxygenase-2 expression is increased in frontal cortex of Alzheimer's disease brain. Neuroscience Nov;1998 87(2):319-324. [PubMed: 9740394]

137. Sainati, SM.; Ingram, DM.; Talwalker, S.; Geis, G. Results of a double-blind, randomized, placebocontrolled study of celecoxib in the treatment of progression of Alzheimer's disease. Paper presented at: Sixth International Stockholm/Springfield Symposium on Advances in Alzheimer Therapy; April 5-8, 2000; Stockholm, Sweden. 2000.

138. Mukherjee D, Nissen SE, Topol EJ. Risk of cardiovascular events associated with selective COX-2 inhibitors. Jama Aug 22-29;2001 286(8):954-959. [PubMed: 11509060]

139. Topol EJ. Failing the public health--rofecoxib, Merck, and the FDA. N Engl J Med Oct 21;2004 351(17):1707-1709. [PubMed: 15470193]

140. Launer L. Nonsteroidal anti-inflammatory drug use and the risk for Alzheimer's disease: dissecting the epidemiological evidence. Drugs 2003;63(8):731-739. [PubMed: 12662122]

141. in t' Veld BA, Ruitenberg A, Hofman A, et al. Nonsteroidal antiinflammatory drugs and the risk of Alzheimer's disease. N Engl J Med Nov 22;2001 345(21):1515-1521. [PubMed: 11794217]

142. Weggen S, Eriksen JL, Das P, et al. A subset of NSAIDs lower amyloidogenic Abeta42 independently of cyclooxygenase activity. Nature Nov 8;2001 414(6860):212-216. [PubMed: 11700559]

143. Weggen S, Eriksen JL, Sagi SA, et al. Evidence that nonsteroidal anti-inflammatory drugs decrease amyloid beta 42 production by direct modulation of gamma-secretase activity. J Biol Chem Aug 22;2003 278(34):31831-31837. [PubMed: 12805356] 
144. Henderson VW, Paganini-Hill A, Emanuel CK, Dunn ME, Buckwalter JG. Estrogen replacement therapy in older women. Comparisons between Alzheimer's disease cases and nondemented control subjects. Arch Neurol Sep;1994 51(9):896-900. [PubMed: 8080389]

145. Kawas C, Resnick S, Morrison A, et al. A prospective study of estrogen replacement therapy and the risk of developing Alzheimer's disease: the Baltimore Longitudinal Study of Aging. Neurology Jun;1997 48(6):1517-1521. [PubMed: 9191758]

146. Paganini-Hill A, Henderson VW. Estrogen deficiency and risk of Alzheimer's disease in women. Am J Epidemiol Aug 1;1994 140(3):256-261. [PubMed: 8030628]

147. Paganini-Hill A, Henderson VW. Estrogen replacement therapy and risk of Alzheimer disease. Arch Intern Med Oct 28;1996 156(19):2213-2217. [PubMed: 8885820]

148. Shumaker SA, Legault C, Rapp SR, et al. Estrogen plus progestin and the incidence of dementia and mild cognitive impairment in postmenopausal women: the Women's Health Initiative Memory Study: a randomized controlled trial. Jama May 28;2003 289(20):2651-2662. [PubMed: 12771112]

149. Rapp SR, Espeland MA, Shumaker SA, et al. Effect of estrogen plus progestin on global cognitive function in postmenopausal women: the Women's Health Initiative Memory Study: a randomized controlled trial. Jama May 28;2003 289(20):2663-2672. [PubMed: 12771113]

150. Shumaker SA, Legault C, Kuller L, et al. Conjugated equine estrogens and incidence of probable dementia and mild cognitive impairment in postmenopausal women: Women's Health Initiative Memory Study. Jama Jun 23;2004 291(24):2947-2958. [PubMed: 15213206]

151. Espeland MA, Rapp SR, Shumaker SA, et al. Conjugated equine estrogens and global cognitive function in postmenopausal women: Women's Health Initiative Memory Study. Jama Jun 23;2004 291(24):2959-2968. [PubMed: 15213207]

152. Sano M. Moving from treatment to prevention in Alzheimer's disease with vitamin $E$ and estrogen. Psychiatric Times 1999;16:1-4.

153. McBee WL, Dailey ME, Dugan E, Shumaker SA. Hormone replacement therapy and other potential treatments for dementias. Endocrinol Metab Clin North Am Jun;1997 26(2):329-345. [PubMed: 9193887]

154. Mulnard RA, Cotman CW, Kawas C, et al. Estrogen replacement therapy for treatment of mild to moderate Alzheimer disease: a randomized controlled trial. Alzheimer's Disease Cooperative Study. Jama Feb 23;2000 283(8):1007-1015. [PubMed: 10697060]

155. Henderson VW, Paganini-Hill A, Miller BL, et al. Estrogen for Alzheimer's disease in women: randomized, double-blind, placebo-controlled trial. Neurology Jan 25;2000 54(2):295-301. [PubMed: 10668686]

156. Roberts RO, Cha RH, Knopman DS, Petersen RC, Rocca WA. Postmenopausal estrogen therapy and Alzheimer disease: overall negative findings. Alzheimer Dis Assoc Disord Jul-Sep;2006 20(3): 141-146. [PubMed: 16917183]

157. Masters CL, Beyreuther K. Alzheimer's centennial legacy: prospects for rational therapeutic intervention targeting the Abeta amyloid pathway. Brain Nov;2006 129(Pt 11):2823-2839. [PubMed: 17012295]

158. Selkoe DJ. The genetics and molecular pathology of Alzheimer's disease: roles of amyloid and the presenilins. Neurol Clin Nov;2000 18(4):903-922. [PubMed: 11072267]

159. Hussain I, Powell D, Howlett DR, et al. Identification of a novel aspartic protease (Asp 2) as betasecretase. Mol Cell Neurosci Dec;1999 14(6):419-427. [PubMed: 10656250]

160. Sinha S, Anderson JP, Barbour R, et al. Purification and cloning of amyloid precursor protein betasecretase from human brain. Nature Dec 2;1999 402(6761):537-540. [PubMed: 10591214]

161. Vassar R, Bennett BD, Babu-Khan S, et al. Beta-secretase cleavage of Alzheimer's amyloid precursor protein by the transmembrane aspartic protease BACE. Science Oct 22;1999 286(5440): 735-741. [PubMed: 10531052]

162. Yan R, Bienkowski MJ, Shuck ME, et al. Membrane-anchored aspartyl protease with Alzheimer's disease beta-secretase activity. Nature Dec 2;1999 402(6761):533-537. [PubMed: 10591213]

163. Garino C, Tomita T, Pietrancosta N, et al. Naphthyl and coumarinyl biarylpiperazine derivatives as highly potent human beta-secretase inhibitors. Design, synthesis, and enzymatic BACE-1 and cell assays. J Med Chem Jul 13;2006 49(14):4275-4285. [PubMed: 16821787] 
164. Siemers ER, Quinn JF, Kaye J, et al. Effects of a gamma-secretase inhibitor in a randomized study of patients with Alzheimer disease. Neurology Feb 28;2006 66(4):602-604. [PubMed: 16505324]

165. Dovey HF, John V, Anderson JP, et al. Functional gamma-secretase inhibitors reduce beta-amyloid peptide levels in brain. J Neurochem Jan;2001 76(1):173-181. [PubMed: 11145990]

166. Eriksen JL, Sagi SA, Smith TE, et al. NSAIDs and enantiomers of flurbiprofen target gammasecretase and lower Abeta 42 in vivo. J Clin Invest Aug;2003 112(3):440-449. [PubMed: 12897211]

167. Anderson JJ, Holtz G, Baskin PP, et al. Reductions in beta-amyloid concentrations in vivo by the gamma-secretase inhibitors BMS-289948 and BMS-299897. Biochem Pharmacol Feb 15;2005 69 (4):689-698. [PubMed: 15670587]

168. Black S, Wilcock G, Haworth J, et al. Efficacy and safety of MPC-7869 (R-flurbiprofen), a selective ab42-lowering agent, in mild Alzheimer's disease (AD): Results of a 12-month Phase 2 trial and 1-year follow-on study. Neurology MAR 14 2006;2006 66(5 Suppl 2):A347-A347.

169. Schenk D, Barbour R, Dunn W, et al. Immunization with amyloid-beta attenuates Alzheimerdisease-like pathology in the PDAPP mouse. Nature Jul 8;1999 400(6740):173-177. [PubMed: 10408445]

170. Orgogozo JM, Gilman S, Dartigues JF, et al. Subacute meningoencephalitis in a subset of patients with AD after Abeta42 immunization. Neurology Jul 8;2003 61(1):46-54. [PubMed: 12847155]

171. Gilman S, Koller M, Black RS, et al. Clinical effects of Abeta immunization (AN1792) in patients with AD in an interrupted trial. Neurology May 10;2005 64(9):1553-1562. [PubMed: 15883316]

172. Masliah E, Hansen L, Adame A, et al. Abeta vaccination effects on plaque pathology in the absence of encephalitis in Alzheimer disease. Neurology Jan 11;2005 64(1):129-131. [PubMed: 15642916]

173. Fox NC, Black RS, Gilman S, et al. Effects of Abeta immunization (AN1792) on MRI measures of cerebral volume in Alzheimer disease. Neurology May 10;2005 64(9):1563-1572. [PubMed: 15883317]

174. Dodel R, Hampel H, Depboylu C, et al. Human antibodies against amyloid beta peptide: a potential treatment for Alzheimer's disease. Ann Neurol Aug;2002 52(2):253-256. [PubMed: 12210803]

175. Dodel RC, Du Y, Depboylu C, et al. Intravenous immunoglobulins containing antibodies against beta-amyloid for the treatment of Alzheimer's disease. J Neurol Neurosurg Psychiatry Oct;2004 75 (10):1472-1474. [PubMed: 15377700]

176. Adamiak B, Monthe C, Bender H, et al. Intravenous immunoglobulin (IVIg) maintains cognition over 18 months in patients with Alzheimer's disease (AD). Alzheimer's \& Dementia: The Journal of the Alzheimer's Association 2006/07 2006;2(3):S62-S63.

177. Chung JA, Cummings JL. Neurobehavioral and neuropsychiatric symptoms in Alzheimer's disease: characteristics and treatment. Neurol Clin Nov;2000 18(4):829-846. [PubMed: 11072263]

178. Henderson DC, Cagliero E, Copeland PM, et al. Glucose metabolism in patients with schizophrenia treated with atypical antipsychotic agents: a frequently sampled intravenous glucose tolerance test and minimal model analysis. Arch Gen Psychiatry Jan;2005 62(1):19-28. [PubMed: 15630069]

179. Ballard C, Bannister C, Solis M, Oyebode F, Wilcock G. The prevalence, associations and symptoms of depression amongst dementia sufferers. J Affect Disord Jan 22;199636(3-4):135-144. [PubMed: 8821316]

180. Borson S, Raskind MA. Clinical features and pharmacologic treatment of behavioral symptoms of Alzheimer's disease. Neurology May;1997 48(5 Suppl 6):S17-24. [PubMed: 9153156]

181. Devanand DP, Jacobs DM, Tang MX, et al. The course of psychopathologic features in mild to moderate Alzheimer disease. Arch Gen Psychiatry Mar;1997 54(3):257-263. [PubMed: 9075466]

182. Mega MS, Cummings JL, Fiorello T, Gornbein J. The spectrum of behavioral changes in Alzheimer's disease. Neurology Jan;1996 46(1):130-135. [PubMed: 8559361]

183. Reisberg B, Borenstein J, Salob SP, Ferris SH, Franssen E, Georgotas A. Behavioral symptoms in Alzheimer's disease: phenomenology and treatment. J Clin Psychiatry May;1987 48 (Suppl):9-15. [PubMed: 3553166]

184. Cohen-Mansfield J, Deutsch LH. Agitation: Subtypes and Their Mechanisms. Semin Clin Neuropsychiatry Oct;1996 1(4):325-339. [PubMed: 10320435]

185. Cummings JL, Mega M, Gray K, Rosenberg-Thompson S, Carusi DA, Gornbein J. The Neuropsychiatric Inventory: comprehensive assessment of psychopathology in dementia. Neurology Dec;1994 44(12):2308-2314. [PubMed: 7991117] 
186. Kaufer DI, Cummings JL, Ketchel P, et al. Validation of the NPI-Q, a brief clinical form of the Neuropsychiatric Inventory. J Neuropsychiatry Clin Neurosci Spring;2000 12(2):233-239. [PubMed: 11001602]

187. Devanand DP, Sano M, Tang MX, et al. Depressed mood and the incidence of Alzheimer's disease in the elderly living in the community. Arch Gen Psychiatry Feb;1996 53(2):175-182. [PubMed: 8629893]

188. Cooper JK, Mungas D, Verma M, Weiler PD. Psychotic symptoms in Alzheimer's disease. Int J Geriatr Psychiatry 1991;6(10):721-726.

189. Rubin EH, Drevets WC, Burke WJ. The nature of psychotic symptoms in senile dementia of the Alzheimer type. J Geriatr Psychiatry Neurol Jan;1988 1(1):16-20. [PubMed: 3266997]

190. Stern Y, Albert M, Brandt J, et al. Utility of extrapyramidal signs and psychosis as predictors of cognitive and functional decline, nursing home admission, and death in Alzheimer's disease: prospective analyses from the Predictors Study. Neurology Dec;1994 44(12):2300-2307. [PubMed: 7991116]

191. Katz IR, Jeste DV, Mintzer JE, Clyde C, Napolitano J, Brecher M. Comparison of risperidone and placebo for psychosis and behavioral disturbances associated with dementia: a randomized, doubleblind trial. Risperidone Study Group. J Clin Psychiatry Feb;1999 60(2):107-115. [PubMed: 10084637]

192. McManus DQ, Arvanitis LA, Kowalcyk BB. Quetiapine, a novel antipsychotic: experience in elderly patients with psychotic disorders. Seroquel Trial 48 Study Group. J Clin Psychiatry May;1999 60 (5):292-298. [PubMed: 10362435]

193. Street JS, Clark WS, Gannon KS, et al. Olanzapine treatment of psychotic and behavioral symptoms in patients with Alzheimer disease in nursing care facilities: a double-blind, randomized, placebocontrolled trial. The HGEU Study Group. Arch Gen Psychiatry Oct;2000 57(10):968-976. [PubMed: 11015815]

194. Schneider LS, Tariot PN, Dagerman KS, et al. Effectiveness of atypical antipsychotic drugs in patients with Alzheimer's disease. N Engl J Med Oct 12;2006 355(15):1525-1538. [PubMed: 17035647]

195. Schneider LS, Dagerman K, Insel PS. Efficacy and adverse effects of atypical antipsychotics for dementia: meta-analysis of randomized, placebo-controlled trials. Am J Geriatr Psychiatry Mar; 2006 14(3):191-210. [PubMed: 16505124]

196. McAllister TW. Apathy. Semin Clin Neuropsychiatry Oct;2000 5(4):275-282. [PubMed: 11291024]

197. Deutsch LH, Bylsma FW, Rovner BW, Steele C, Folstein MF. Psychosis and physical aggression in probable Alzheimer's disease. Am J Psychiatry Sep;1991 148(9):1159-1163. [PubMed: 1882992]

198. Sultzer DL, Gray KF, Gunay I, Berisford MA, Mahler ME. A double-blind comparison of trazodone and haloperidol for treatment of agitation in patients with dementia. Am J Geriatr Psychiatry Winter; 1997 5(1):60-69. [PubMed: 9169246]

199. Tariot PN, Erb R, Podgorski CA, et al. Efficacy and tolerability of carbamazepine for agitation and aggression in dementia. Am J Psychiatry Jan;1998 155(1):54-61. [PubMed: 9433339]

200. Porsteinsson AP, Tariot PN, Erb R, Gaile S. An open trial of valproate for agitation in geriatric neuropsychiatric disorders. Am J Geriatr Psychiatry Fall;1997 5(4):344-351. [PubMed: 9363292] 


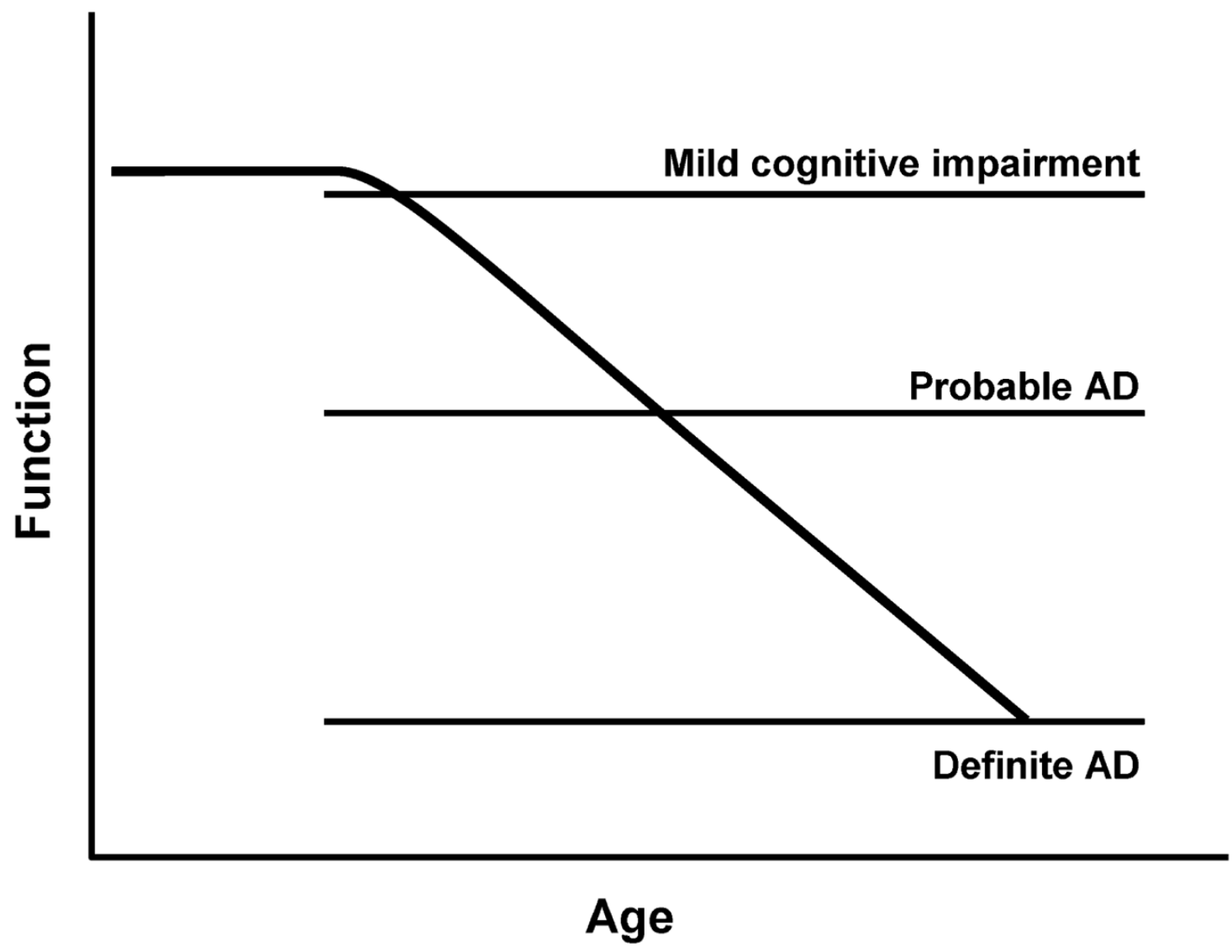

Figure 1.

Theoretical progression of cognitive function from normal through mild cognitive impairment to probable and definite Alzheimer's Disease (AD) in persons destined to develop AD. Reprinted with permission from Saunders 2 . 


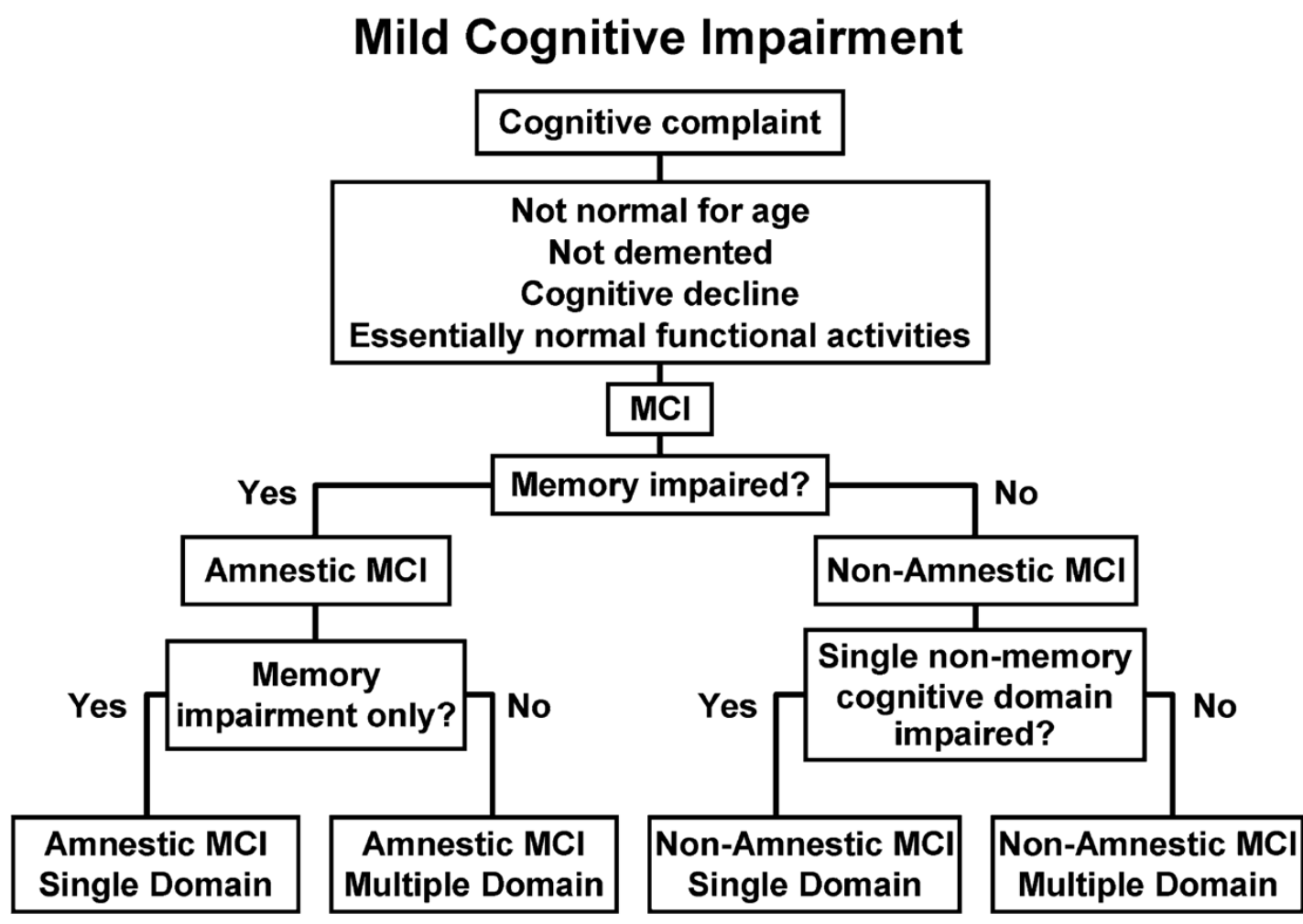

Figure 2.

Flow diagram for diagnosing MCI. The cardinal feature is cognitive impairment intermediate between the cognitive changes of normal aging and those of early dementia. Subtyping of MCI is first made along the dimension of memory into amnestic and non-amnestic. These subtypes are further classified into single cognitive domain or multiple cognitive domains. See text for explanation. 


\section{Subtypes}

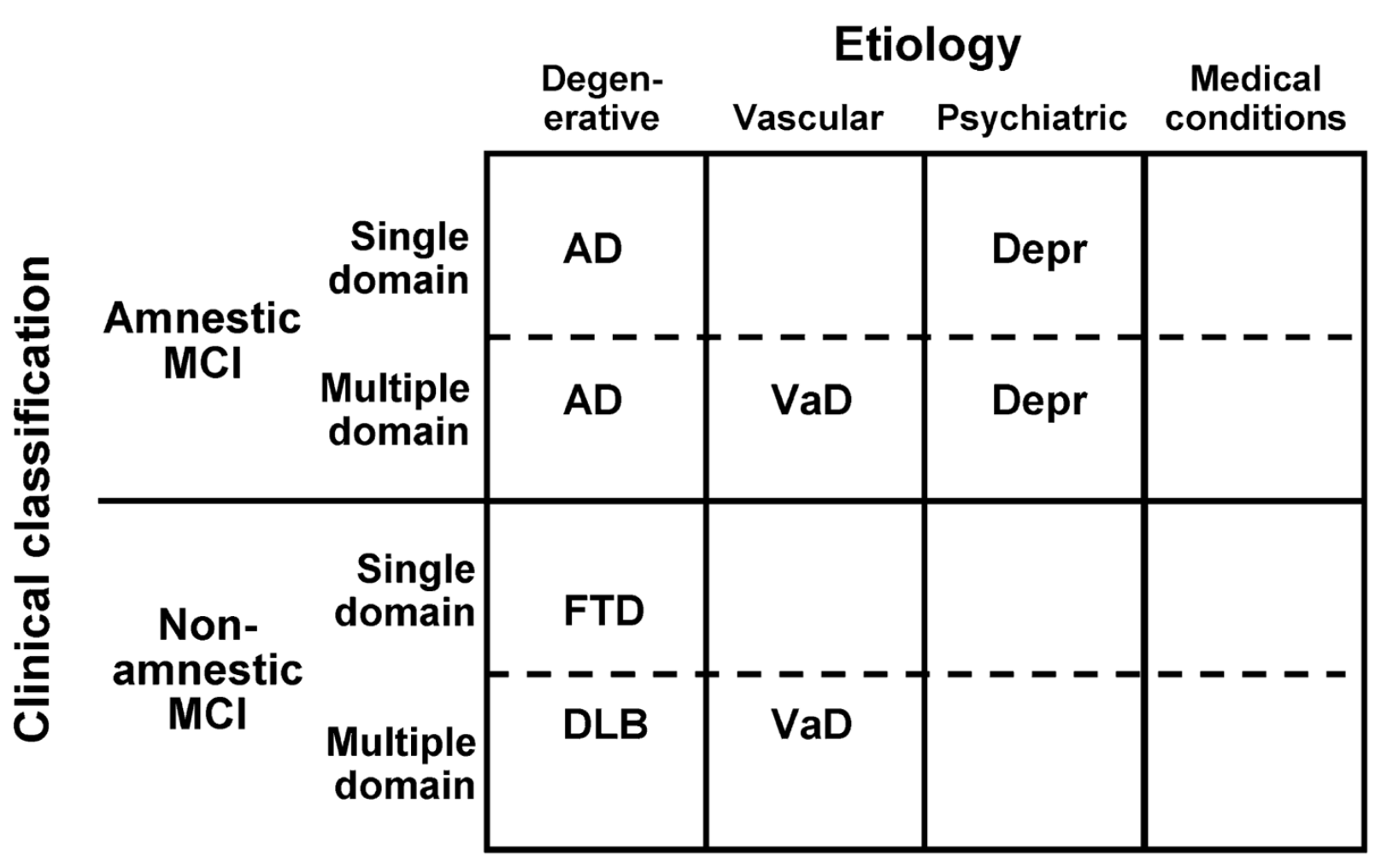

Figure 3.

The four clinical subtypes of MCI are then combined with the presumed etiology of the clinical syndrome. For example, amnestic MCI of single or multiple domain subtypes can be combined with the presumed degenerative etiology to result in the likely outcome of Alzheimer's disease when the condition progresses to dementia. The other suggested clinical outcomes are theoretical and other outcomes may be possible. 

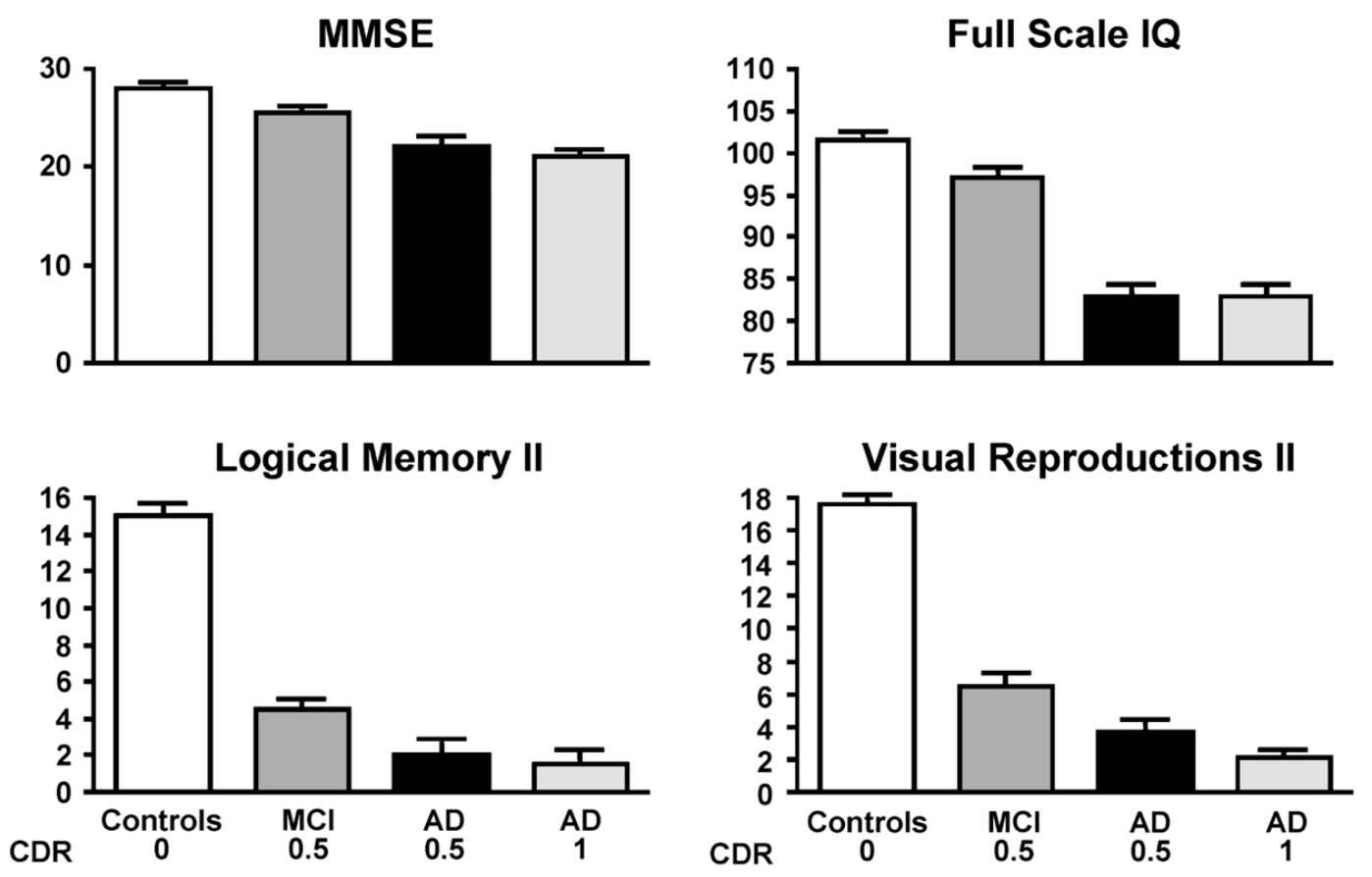

Figure 4.

Cognitive profile of persons with a mild cognitive impairment. The top two panels, MiniMental State Exam (MMSE) and Full Scale IQ represent measures of general intellectual function. The bottom two panels represent memory function for verbal memory (Logical Memory II) and non-verbal memory (Visual Reproductions II). Reprinted with permission from the American Medical Association 80 . 
TABLE 1

DIAGNOSTIC CRITERIA FOR DEMENTIA OF THE ALZHEIMER'S TYPE

A. Memory Impairment

Learning or Recall

B. One or More
i. Aphasia
ii. Apraxia
iii. Agnosia
iv. Dysexecutive Function (Planning, Organizing, Sequencing, Abstracting)

C. Cognitive Deficits of Sufficient Severity to Affect Social or Occupational Functioning and this Represents a Change from Previous Level

D. Clinical Course has Gradual Onset and Progressive Course

E. Not Due to Delirium

F. No Alternative Central Nervous System Explanation, e.g., Stroke, Parkinson's Disease 
TABLE 2

EVALUATION OF PATIENTS WITH DEMENTIA

\begin{tabular}{|c|c|}
\hline ROUTINE & OPTIONAL \\
\hline Electrolytes & Sedimentation rate \\
\hline Complete blood count & Drug levels \\
\hline Vitamin $B_{12}$ level ${ }^{*}$ & HIV testing \\
\hline Thyroid function studies ${ }^{*}$ & Lyme serology \\
\hline \multirow[t]{2}{*}{ Syphilis serology } & Urinalysis \\
\hline & 24-urine for heavy metal \\
\hline \multirow[t]{5}{*}{$\mathrm{CT} / \mathrm{MRI}^{*}$} & Cerebrospinal fluid \\
\hline & Chest x-ray \\
\hline & Electrocardiogram \\
\hline & Electroencephalogram \\
\hline & PET/SPECT \\
\hline
\end{tabular}

Suggested by the American Academy of Neurology 4 . 
TABLE 3

CLINICAL CRITERIA FOR MILD COGNITIVE IMPAIRMENT

1 Cognitive Complaint (usually memory) - Preferably Corroborated by an Informant

2 Cognitive Impairment (usually memory) for Age and Education

3 Essentially Normal General Cognitive Function

$4 \quad$ Largely Preserved Activities of Daily Living

$5 \quad$ Not Demented 


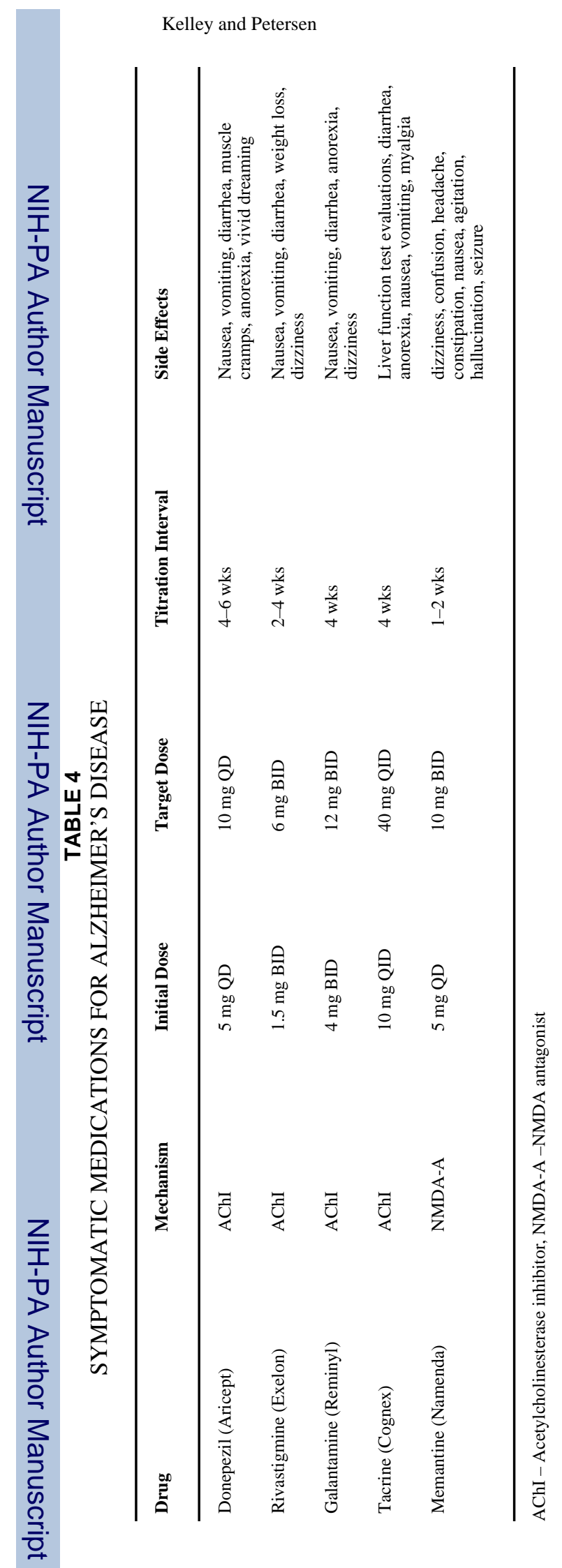

Page 32

Neurol Clin. Author manuscript; available in PMC 2009 May 14. 
TABLE 5

FREQUENCY OF BEHAVIORAL DISORDERS IN ALZHEIMER'S DISEASE

\begin{tabular}{ll}
\hline Agitation & $50-70 \%$ \\
Anxiety & $30-50 \%$ \\
Depression & $25-50 \%$ \\
Disinhibition & $20-35 \%$ \\
Aggression & $25 \%$ \\
Delusions & $15-50 \%$ \\
Hallucinations & $10-25 \%$ \\
Sexual Disinhibition & $5-10 \%$ \\
\hline
\end{tabular}

(Please see Reference 183) 
TABLE 6

MEDICATIONS FOR NON-COGNITIVE SYMPTOMS IN DEMENTIA

\begin{tabular}{|c|c|c|}
\hline Class & Agents & Usual Daily Dose \\
\hline Delusions & $\begin{array}{l}\text { Risperidone (Risperdal) } \\
\text { Olanzapine (Zyprexa) } \\
\text { Quetiapine (Seroquel) } \\
\text { Aripiprazole (Abilify) } \\
\text { Haloperidol (Haldol) }\end{array}$ & $\begin{array}{l}1 \mathrm{mg}(.05-2 \mathrm{mg}) \\
5 \mathrm{mg}(5-10 \mathrm{mg}) \\
400 \mathrm{mg}(50-400 \mathrm{mg}) \\
5 \mathrm{mg}(5-20 \mathrm{mg}) \\
1 \mathrm{mg}(.5-3 \mathrm{mg})\end{array}$ \\
\hline Agitation/aggression & $\begin{array}{l}\text { Risperidone (Risperdal) } \\
\text { Olanzapine (Zyprexa) } \\
\text { Quetiapine (Seroquel) } \\
\text { Aripiprazole (Abilify) } \\
\text { Haloperidol (Haldol) } \\
\text { Trazodone (Desyrel) } \\
\text { Buspirone (Buspar) } \\
\text { Propranolol (Inderal) } \\
\text { Carbamazepine (Tegretol) } \\
\text { Divalproex (Depakote) } \\
\text { Lorazepam (Ativan) }\end{array}$ & $\begin{array}{l}1 \mathrm{mg}(.05-2 \mathrm{mg}) \\
5 \mathrm{mg}(5-10 \mathrm{mg}) \\
400(50-400 \mathrm{mg}) \\
5 \mathrm{mg}(5-20 \mathrm{mg}) \\
1 \mathrm{mg}(.5-3 \mathrm{mg}) \\
100 \mathrm{mg}(100-400 \mathrm{mg}) \\
15 \mathrm{mg}(15-30 \mathrm{mg}) \\
120 \mathrm{mg}(80-240 \mathrm{mg}) \\
400 \mathrm{mg}(200-1200 \mathrm{mg}) \\
500 \mathrm{mg}(250-2000 \mathrm{mg}) \\
1 \mathrm{mg}(0.5-6 \mathrm{mg})\end{array}$ \\
\hline Depression & $\begin{array}{l}\text { Fluoxetine (Prozac) } \\
\text { Sertraline (Zoloft) } \\
\text { Paroxetine (Paxil) } \\
\text { Citalopram (Celexa) } \\
\text { Venlafaxin (Effexor) } \\
\text { Nefazodone (Serzone) } \\
\text { Mirtazepine (Remeron) } \\
\text { Duloxetine (Cymbalta) } \\
\text { Nortriptyline (Pamelor) } \\
\text { Trazodone (Desyrel) }\end{array}$ & $\begin{array}{l}20 \mathrm{mg}(20-40 \mathrm{mg}) \\
50 \mathrm{mg}(50-200 \mathrm{mg}) \\
20 \mathrm{mg}(10-50 \mathrm{mg}) \\
20 \mathrm{mg}(10-30 \mathrm{mg}) \\
100 \mathrm{mg}(50-225 \mathrm{mg}) \\
400 \mathrm{mg}(200-600 \mathrm{mg}) \\
15 \mathrm{mg}(7.5-30 \mathrm{mg}) \\
20 \mathrm{mg}(20-60 \mathrm{mg}) \\
50 \mathrm{mg}(50-100 \mathrm{mg}) \\
50 \mathrm{mg}(100-400 \mathrm{mg}) \\
\end{array}$ \\
\hline Anxiety & $\begin{array}{l}\text { Oxazepam (Serax) } \\
\text { Lorazepam (Ativan) } \\
\text { Buspirone (Buspar) } \\
\text { Propranolol (Inderal) }\end{array}$ & $\begin{array}{l}30 \mathrm{mg}(20-60 \mathrm{mg}) \\
1 \mathrm{mg}(0.5-6 \mathrm{mg}) \\
30 \mathrm{mg}(15-45 \mathrm{mg}) \\
120 \mathrm{mg}(80-240)\end{array}$ \\
\hline Insomnia & $\begin{array}{l}\text { Trazodone (Desyrel) } \\
\text { Zolpidem (Ambien) } \\
\text { Temazepam (Restoril) } \\
\text { Zoloplon (Sonata) }\end{array}$ & $\begin{array}{l}50 \mathrm{mg}(50-200 \mathrm{mg}) \\
10 \mathrm{mg}(5-10 \mathrm{mg}) \\
15 \mathrm{mg}(15-30 \mathrm{mg}) \\
10 \mathrm{mg}\end{array}$ \\
\hline Apathy & $\begin{array}{l}\text { Donepezil (Aricept) } \\
\text { Rivastigmine (Exelon) }\end{array}$ & $\begin{array}{l}10 \mathrm{mg}(5-10 \mathrm{mg}) \\
9 \mathrm{mg}(6-12 \mathrm{mg})\end{array}$ \\
\hline
\end{tabular}

